


\section{The Agricultural Survey of Afghanistan}

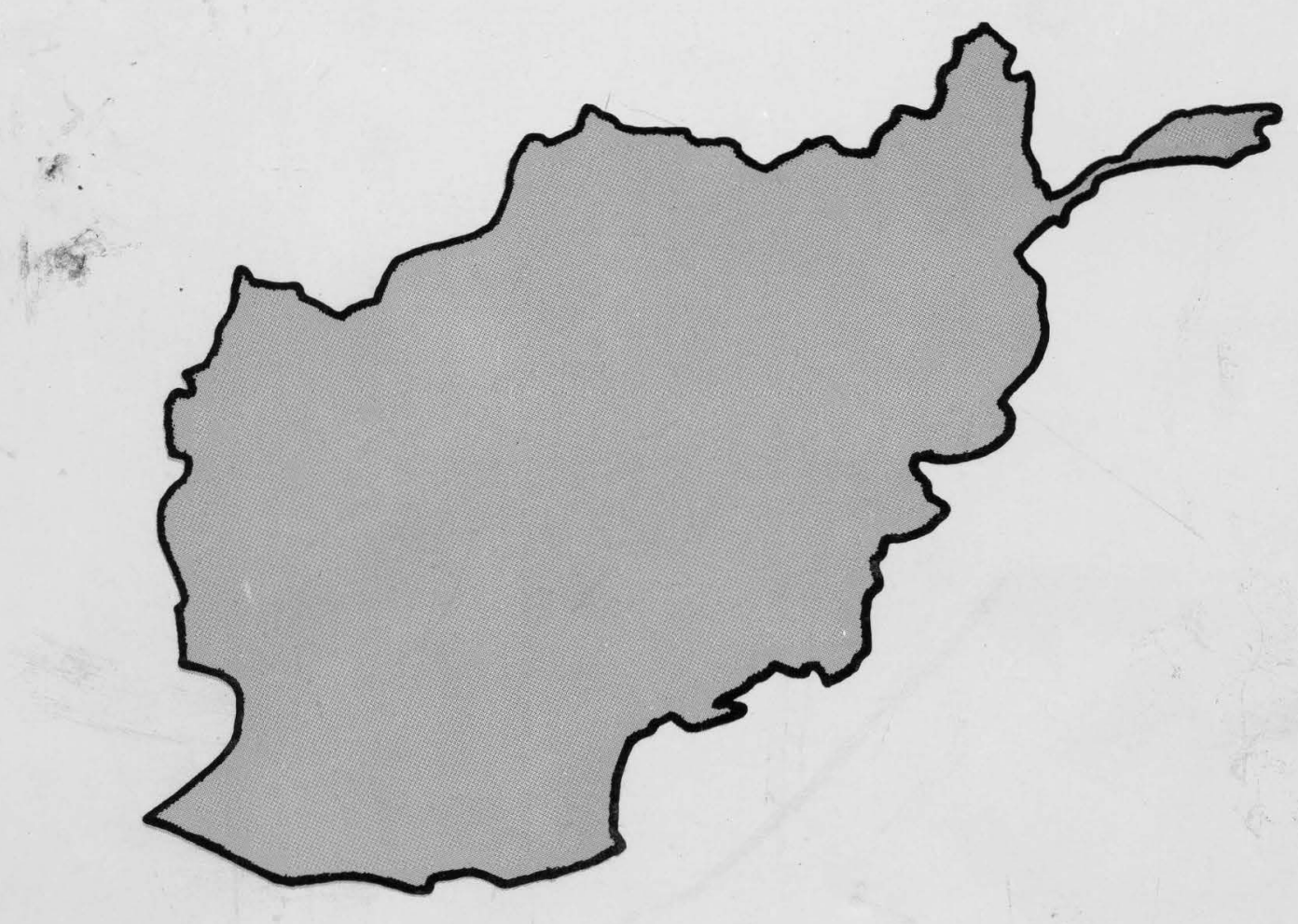

The Swedish Committee for Afghanistan 
EIGHTH REPORT

NORTHERN AFGHANISTAN

INSECT DAMAGE SURVEY

OCTOBER

1990 
TABLE OF CONTENTS

SECTION A. MAIN REPORT

ACKNOWLEDGEMENTS
SUMMARY

1. INTRODUCTION

Background

Summary of the 1989/90 Northern Afghanistan Programme

Methodology

2. SURVEY RESULTS - DISTRICT PROFILES

3. GENERAL AGRICULTURAL SITUATION IN THE AFFECTED AREAS

4. SUMMARY OF PROJECTS ARISING FROM THE SURVEY

SECTION B. SURVEY RESULTS

\section{B1. LOCUST AND SUNNPEST DAMAGE}

\begin{tabular}{ll} 
Table 1. & Badghis \\
Table 2. & Badghis \\
Table 3. & Faryab \\
Table 4. & Faryab \\
Table 5. & Faryab \\
Table 6. & Jowzjan \\
Table 7. & Jowzjan \\
Table 8. & Jowzjan \\
Table 9. & Samangan \\
Table 10. & Samangan \\
Table 11. & Samangan \\
Table 12. & Baghlan \\
Table 13. & Baghlan \\
Table 14. & Baghlan \\
Table 15. & Kunduz \\
Table 16. & Kunduz \\
Table 17. & Kunduz \\
Table 18. & Takhar \\
Table 19. & Takhar \\
Table 20. & Takhar \\
Table 21. & Badakhshan \\
Table 22. & Badakhshan \\
Table 23. & Badakhshan \\
Table 24. & Herat \\
Table 25. & Herat \\
Table 26. & Herat \\
\hline
\end{tabular}

Sunn pest and locusts on Sunn pest and locusts on Sunn pest and locusts on Sunn pest and locusts on Sunn pest and locusts on Sunn pest and locusts on Sunn pest and locusts on Sunn pest and locusts on Sunn pest and locusts on Sunn pest and locusts on Sunn pest and locusts on Sunn pest and locusts on Sunn pest and locusts on Sunn pest and locusts on Sunn pest and locusts on Sunn pest and locusts on Sunn pest and locusts on Sunn pest and locusts on Sunn pest and locusts on Sunn pest and locusts on Sunn pest and locusts on Sunn pest and locusts on Sunn pest and locusts on Sunn pest and locusts on Sunn pest and locusts on Sunn pest and locusts on rainfed wheat barley irrigated wheat rainfed wheat barley irrigated wheat rainfed wheat barley irrigated wheat rainfed wheat barley irrigated wheat rainfed wheat barley irrigated wheat rainfed wheat barley irrigated wheat rainfed wheat barley irrigated wheat rainfed wheat barley irrigated rainfed wheat barley 
B2. CONSTRAINTS ON CROP PRODUCTION DERIVED FROM THE 1989 GENERAL SURVEY

Table 27. Problems as perceived by farmers, Baghlan, Takhar, Kunduz, Badakhshan

Table 28. Problems as perceived by farmers, Faryab, Balkh, Samangan, Jowzjan

Table 29. Problems as perceived by farmers, Badghis 


\section{ACKNOWLEDGEMENTS}

Direct costs of this survey were paid for out of Swedish Committee for Afghanistan (SCA) programme funds which are largely derived from the Swedish International Development Agency (SIDA). UNDP/OPS paid for general overheads, being management, training, and computer staff salaries. This report is produced under contract to UNDP/OPS.

The Agricultural Survey of Afghanistan (ASA) is a section of the Department of Agriculture of the SCA. The ASA would like to thank the farmers, shuras and commanders who cooperated in the survey again this year. Special acknowledgement is also due to the Deputy Director of the ASA, Abdullah Naik, who was in overall charge of the Insect Damage Survey, and to Abdul Hakim who was in charge of training and day-to-day management of the twenty enumerators. Particular acknowledgement also goes to Suleiman and his team of computer operators in the ASA Computer Division.

The British Overseas Development Administration (ODA) made available the services of Agrisystems which provided technical support to the Computer Division and assisted in the preparation of this report. ODA also provided the computer equipment used by the Computer Division.

The ASA acknowledges with thanks the support of UNDP/OPS and ODA but neither bears any responsibility for, nor are they committed to, the views and recommendations expressed herein.

This report may be photocopied or quoted with acknowledgement. 


\section{SUMMARY}

i) Those who have read the August 1989 report on the survey last year, or have been involved in the Northern Afghanistan Crop Protection Programme which arose from that report, will want first to know "Is the problem getting better or worse?" The answer, on balance, is neither. It seems to be about the same as last year. In some areas the situation is better and in some it is worse. Significantly, in one district there has been severe damage by Sunn pest in 1.990 where none was reported in 1989.

Broadly speaking, we can identify a worst case category of four provinces (possibly five when Balkh results are in) where farmers face critical losses due to either Sunn pest or locusts or both. These are as follows:

Badghls and Faryab where both Sunn pest and locusts have been serious in all districts surveyed in both years. Badghis is marginally less affected in 1990 and Faryab is generally worse. (Neighbouring Balkh could also be classed in this worst case category but our enumerators have not yet returned).

Jowzjan has been seriously affected mainly by Sunn pest though in some districts locusts have also been devastating. On the whole the situation is better in 1990.

Badakhshan has been seriously affected by locusts only in both years, and losses in nearty all districts are considerably worse in 1990 than in 1989.

iii) Farmers in Samangan and Baghlan have not suffered the same degree of losses as in the worst case category above, and on the whole Sunn pest is not devastatingly damaging. However, while 1990 was a better year than 1989, locusts are still responsible for total crop losses on some farms in some districts. And the example of Darae Souf in Samangan, where Sunn pest was not recorded in 1989, yet affected nearly half the district's farmers in 1990, some of whom lost between a quarter and half their crop, shows that a complacent or relaxed attitude is not appropriate. By any normal measure, these are chronically and badly affected areas which could become much worse at any time. It is only when compared with the four worst provinces above that the infestation appears less serious than it really is.

iv) We can say positively that farmers in the provinces of Kunduz and Takhar have generally suffered little damage from Sunn pest or locusts, and where there was damage from Sunn pest or locusts in 1989, it was less in 1990. We hesitate to put Herat into the same category as Kunduz and Takhar, (although the survey results suggest we should), because the survey covered only the central irrigated part of the province and omitted the rainfed areas. It could be that the average Herati farmer is worse hit than the results show.

v) Those readers who have not been involved before will want first to know the scale of the problem and what is being done about it. First, this report shows that the scale of the problem in the two provinces of Badghis and Faryab is such that farmers consider it to be a greater problem than any other they face. This bland statement arises from the methodology of the survey in which farmers were asked to rank their problems, but the end result is one of devastation for many of them. In Badghis and Faryab in 1990 over $80 \%$ of farmers growing rainfed wheat were affected by Sunn pest and locusts and over a quarter of them lost up to half their crop. In these provinces rainfed farming predominates. For example, in Badghis three 
quarters of farmers cultivate rainfed land, and in Faryab three quarters of farmers rely solely on it.

vi) For provinces which are normally grain exporters, (part of the traditional "breadbasket of Afghanistan") these statistics strung together add up to wheat losses measured in hundreds of thousands of tons, hardship for a rural population measured in millions, massive depletion of assets such as livestock for hundreds of thousands of farm families, and the complete loss, at least temporarily, of a way of life for those who are forced to leave farming and become refugees. (See also the Food Deficit Survey, the ASA's Ninth Report). Certainly, the fabric of farming in Northern Afghanistan is in a fragile state after a decade of war, but the effects above are directly attributable to Sunn pest and locust.

vii) The scope and scale of the problem was identified by a special survey of the Swedish Committee's ASA in 1989, and the response in terms of assistance by the aid community was a series of pilot projects to seek long term and environmentally safe solutions to the problem, together with short-term humanitarian food relief, and short-term assistance in the safer use of existing stocks of an environmentally harmful insecticide. The ASA's Seventh Report, the Northern Afghanistan Crop Protection Programme (NACPP), identifies the details of that response.

viii) The experience gained from the pilot projects of the NACPP, together with the results of this survey, has now led to the logical next step which is a comprehensive programme designed to reach nearly all affected farmers on an estimated 500,000 hectares of cultivated land in the 1990/91 cropping season. Safer, more effective, and logistically easier-to-apply insecticides have been identified and tested with farmers, and will be delivered to 17 sites in all affected areas of Northern Afghanistan. At these sites $\mathbf{1 5 0}$ trained extensionists will supervise the use of these insecticides and ultra-low-volume (ULV) sprayers.

ix) Present intentions are that four Peshawar-based NGOs, the SCA, the Norwegian Committee for Afghanistan (NCA), Afghanaid, and the Danish Committee (DACAAR) will implement the field programme with financial support from UNDP/OPS. UNOCA is to arrange for the delivery of insecticide and sprayers. The Government of Japan and other countries are to give the insecticides, and the Government of Britain is to give the sprayers. 


\section{Background}

\section{CHAPTER ONE. INTRODUCTION}

1.1. This report is an account of the ASA's follow-up survey in 1990 to the Sunn pest and Locust Survey of 1989, and follows the Northern Afghanistan Crop Protection Programme (NACPP) report of August 1989. Those not familiar with the NACPP may wish to read that report in conjunction with this one.

1.2. Briefly, the NACPP report identified the nature and scale of the problem on a district by district basis in the 10 of the 11 northern provinces affected, calculated as far as possible the consequences in terms of food deficit, and proposed a programme of pilot and emergency relief projects. This programme was subsequently implemented successfully by the SCA, Afghanaid, the Norwegian Committee, and the Afghan Cultural Assistance Foundation. Financial, diplomatic and logistical support was provided by UNDP and UNOCA operating on both sides of the main political divide in Pakistan and Kabul. The main material result of this diplomatic initiative was the provision by UNOCA of BHC insecticide as well as wheat to some areas under mujahedin control.

\section{Summary of the Northern Afghanistan Crop Protection Programme}

1.3. On a geographical basis there were 13 district based projects which provided the following services and inputs:

extension in insect control, and in chemical weed control to encourage Autumn planting

testing of the effectiveness and farmer acceptance of safer insecticides and sprayers which they also delivered from Pakistan

distribution of improved early-maturing (and therefore Sunn pest-avoiding) wheat seed on a trial basis

assisting in the distribution of $\mathrm{BHC}$, and wheat for food

1.4. These 13 projects were supported by a Peshawar-based training project implemented by the ASA with UNDP/OPS funds under which all the staff of the different NGOs received common training. UNDP/OPS also funded and implemented a radio extension service to farmers affected by the insect outbreaks using the British Broadcasting Corporation Farsi service.

1.5. This report deals only with Insect Damage. This year a separate report is being produced on Food Deficit, though both sets of information were collected on the same survey.

\section{Methodology}

1.6. The methodology was different in 1990 compared to 1989 . The objective in the 1989 survey was to measure the intensity and type of infestation. The objective in the 1990 survey was to concentrate more on the amount of damage, in particular the number and proportion of farmers affected, and the degree to which they have been affected. Moreover, farmers were asked to assess the damage done to their own crops rather than leaving this assessment to the enumerators. This, as expected, allowed a greater number of farmers to be surveyed in a 
shorter time compared with last year. In fact, the 1989 survey related only to the village, whereas in the 1990 survey farmers were asked, separately and individually, their own opinions. This change of emphasis from the village to the farmer was the essential difference between the 1989 and the 1990 surveys.

1.7. The questionnaire was for four farmers in one village. They were asked two sets of questions, one relating to their own damage and one relating to damage in the village as a whole. This acted as a mutual check. The fact that the number of farmers interviewed was limited to four, again allowed a more detailed coverage of the same area and the same number of villages by fewer enumerators.

1.8. 20 enumerators were finally selected from the training course which was established and designed specifically for this survey. They were all newly recruited men, as the ASA regular enumerator staff, who after four seasons of surveying are now up to a high professional standard, were engaged on the national survey of agriculture. (Some of the information obtained from that survey has been used in this report). The use of inexperienced men was unavoidable, but they were subjected to 27 days of intensive training, and most reached an adequate standard of expertise. Each was from the area to be surveyed, and two men were assigned to each of the ten provinces. They travelled by public transport and hired horses where necessary, and travelling time took between two and three weeks each way, so that actual surveying time was between six weeks and two months. The enumerators' total assignment was four months.

1.9. 1,000 questionnaire forms were sent with the enumerators of which 773 were returned. Neither of the two men sent to Balkh have returned, nor have one of the men sent to Takhar and Herat respectively, resulting in half the expected coverage of those two provinces. Additionally, all the information returned by one man from Badghis had to be rejected because of low quality, with the same result as for Takhar and Herat. Debriefing, checking of the questionnaire forms, and data analysis resulted in the rejection of 243 questionnaires, and the remaining 530 were entered into a computerised database - dBaselV.

1.10. On the whole we believe that the picture presented by this survey is correct. However, 27 days of training (we had no more time than this) was insufficient, and the enumerators also lacked experience. This resulted in some low quality completed questionnaire forms. The reader should bear this in mind, particularly when it comes to the detail of district level results, and should not place too much reliance on the figures for the purposes of detailed planning.

1.11. The ASA's general database can be manipulated to print out information in many different ways, of which one, necessarily condensed, is presented here. Several aid agencies have asked for and received information from the database which can be tailored to fit their specific need more closely. This applies also to the Insect Damage Survey. Any agency interested in obtaining a customised report or data print-out should apply to:

The Director, Dr. Azam Gul, Agricultural Survey of Afghanistan, Agriculture Department of the Swedish Committee for Afghanistan, 57C, Gul Mohar Lane, University Town, PESHAWAR, Pakistan.

Tel. 0521-45257/45357. T|x. 52365 SCA PK. Fax. 0521-42519 


\section{CHAPTER TWO. SURVEY RESULTS}

\section{Province of Badghis, district of Qala Nau}

2.1. In 1990 as in $1989,81 \%$ of farmers who grew rainfed wheat were affected by Sunn pest. The severity of damage was marginally less in 1990 than in 1989 in that the majority of farmers who were affected lost between a quarter and half their crop, while in 1990 the majority lost less than a quarter of their crop. The same proportion, $81 \%$, was affected by locusts. Again the damage was marginally less severe in 1990.

2.2. According to the 1989 General Survey $30 \%$ of farmers grew irrigated wheat but none of these was interviewed in the Insect Damage Survey (IDS). No Sunn pest was reported on barley. Sunn pest does not often attack this crop because it is harvested earlier than wheat (but see Jowzjan). The same proportion of farmers, $77 \%$, was affected by locusts in 1990 as in 1989 but the severity of damage was marginally less.

\section{Province of Badghls, district of Khuske Kohna}

2.3. $88 \%$ farmers growing rainfed wheat were affected by Sunn pest in 1989 and in 1990 . The severity of the damage was marginally less in 1990. No farmers growing irrigated wheat were interviewed. The same proportion, 88\%, was affected by locusts but whereas in 1989 nearly half of them lost between a quarter and half of their crop to locusts alone, in 1990 the same proportion of farmers lost less than a quarter of their crop.

2.4. No Sunn pest was reported on barley. Locust damage was reported by the same proportion of farmers, $88 \%$, in 1990 as in 1989 , but again the severity of damage was less. In $198975 \%$ reported between a quarter and half their crop lost, whereas in 1990 all reported less than $25 \%$.

\section{Province of Badghis, district of Qades}

2.5. The proportion of farmers growing rainfed wheat who reported damage from Sunn pest fell from $77 \%$ in 1989 to $68 \%$ in 1990 . At the same time the equivalent figures for damage from locusts fell from $85 \%$ to $65 \%$. Moreover, the severity of damage to both crops was less in 1990 than ir 1989 - marginally less for Sunn pest and moderately less for locusts. There were no reports of farmers growing irrigated wheat.

2.6. There were no reports of Sunn pest on barley. The overall proportion of farmers reporting damage by locusts to barley fell from $82 \%$ in 1989 to $61 \%$ in 1990

Province of Faryab, district of Belcheragh

2.7. There was little change in the level or degree of damage by Sunn pest on irrigated wheat. Ir. both years $36 \%$ of farmers were affected of which nearly a third lost between a quarter and hak their crop to this cause. There was little change either in the extent of locust damage. $56 \%$ of farmers were affected in each year of which $63 \%$ lost between a quarter and half their crop ir 1990 (in 1989 the figure was 64\%).

2.8. Sunn pest damaged rainfed wheat on $81 \%$ of farms which grew the crop in both 1989 and 1990 but the severity of the damage in 1990 was considerably worse. Half the farmers reportec 
damage of between a quarter and half their crop in 1989. In $199068 \%$ reported at least this level of damage, or in $5 \%$ of cases, between $50 \%$ and $75 \%$ damage. Locust damage to rainfed wheat was marginally more serious in 1990 compared to $1989-72 \%$ of farmers growing the crop were affected in each year.

2.9. Sunn pest damage to barley was reported by about $70 \%$ of farmers in 1989 and 1990 . In almost every case they lost up to. $25 \%$ of their crop, a few lost more than this. Damage to barley by locust was marginally worse in 1990 compared to 1989 both in terms of the number of farmers affected and in terms of the degree of severity.

\section{Province of Faryab, district of Shirin Tageb}

2.10. The sample for Shirin Tageb was small - only 10 farmers. Nevertheless, the results are given below.

2.11. The effect of Sunn pest on irrigated wheat was the same in both years - $30 \%$ of farmers who grew the crop were affected of which one third lost between one third and half their crop. Damage by locusts was much worse than this - $70 \%$ of farmers were affected in each year with 1990 showing a much higher proportion of the crop damaged. $30 \%$ lost between half and three quarters of their crop, and $40 \%$ lost between a quarter and half in 1990.

2.12. Rainfed wheat was severely affected by Sunn pest in both years with a marginal improvement in 1990. In each year $90 \%$ of farmers who grew the crop were affected. $60 \%$ lost between a quarter and half their crop in 1989. The marginal improvement was that this figure was $50 \%$ in 1990. Locusts also severely damaged the rainfed crop and again $90 \%$ of farmers were affected. 1990 , when $50 \%$ of farmers lost between a quarter and half their crops, was worse than 1989 when $30 \%$ did so.

2.13. Sunn pest damage on barley affected a large proportion of farmers, $90 \%$, to a small extent. They lost up to a quarter of their crop to this cause. The figures were the same in each year. The effect of locusts on barley was less in 1990, when $90 \%$ of farmers lost up to a quarter of their crop, than in 1989, when $30 \%$ lost between a quarter and half their crop, as well as $60 \%$ losing up to a quarter.

\section{Province of Faryab, district of Darzab}

2.14. No Sunn pest or locusts were reported on irrigated wheat. But Sunn pest damage on rainfed wheat was severe and was marginally worse in 1990 than in 1989. In $199085 \%$ of farmers were affected and $75 \%$ lost between a quarter and half their crop. Locusts also severely damaged rainfed wheat with $85 \%$ of farmers affected in each year, and were also worse in terms of the degree of damage in 1990, than in 1989. In $199037 \%$ of farmers who grew the crop lost between a quarter and half their crop.

2.15. A large proportion of farmers suffered moderate damage to barley in both years, though it was marginally worse in 1990 when $68 \%$ of farmers lost up to a quarter of their crop. Fewer farmers had locust damage on barley - 61\% in 1989 and 65\% in 1990 - but the effect was more severe with 35\% losing between a quarter and half their crop in 1990, a figure up from 32\% in 1989. 


\section{Province of Jowzjan, distrlct of Sheberghan}

2.16. No Sunn pest or locusts were reported on irrigated wheat or barley. But $100 \%$ (of this IC sample of 5 farmers) repoited up to $25 \%$ losses by Sunn pest on rainfed wheat. The assessment of their neighbours in the village was much higher than this.

\section{Province of Jowzjan, distrlct of Sang Charak}

2.17. Not many farmers reported damage to irrigated wheat by Sunn pest - a total of $12 \%$ in eac year. But some of those reported high losses, even up to $100 \%$. Only $3 \%$ of farmers reporte losses from locusts, in each case of between a quarter and half their crop.

2:18. A remarkably high proportion of farmers growing rainfed wheat reported damage by Sunn pe - 94\% in each year. A quarter of them in 1989 estimated their losses at between $75 \%$ and $100 \%$ In 1990 the situation is marginally better with the number of farmers affected down to $3 \%$ fro $25 \%$, but still $30 \%$ of farmers estimated losses of half to three quarters, and $25 \%$ of farme estimate losses of a quarter to half their crop. Locusts affected $56 \%$ of farmers in each year, b the severity of loss is greater in 1990 with $22 \%$ reporting losses of between a quarter and he their crop, up from $9 \%$ in 1989.

2.19. Barley is less severely affected with $25 \%$ of farmers who grew the crop reporting damage $t$ Sunn pest. $14 \%$ reported damage by locusts, mainly causing losses less than a quarter of th crop.

Province of Jowzjan, district of Sarl Pul

2.20. No farmers were interviewed who grew irrigated wheat.

2.21. Sunn pest infestation on rainfed wheat was widespread with $97 \%$ of farmers reporting at lea: some damage in 1989 and 1990. The situation was somewhat improved in 1990 in the whereas $83 \%$ of farmers reported between three quarters and $100 \%$ damage in 1989 , this yea the same proportion of farmers reported that half to three quarters of their crop was damagec Locust damage was reported by half the farmers who grew rainfed wheat in 1989 and 1990 . C these, half lost up to half their crop, and a quarter lost $100 \%$ in 1989 . The severity of loss wa somewhat less in 1990.

2.22. Sunn pest damage on barley was unusually severe with nearly three quarters of farmer reporting some damage, and half of them reporting between three quarters and $100 \%$ loss $i$ 1989. The numbers of farmers reporting loss in 1990 was the same, but the severity of loss wa somewhat less. Locust damage on barley was reported by $25 \%$ of farmers in each year, an again the severity of loss was a little less in 1990.

\section{Province of Jowzjan, dlstrlct of Kohlstanat}

2.23. Sunn pest damage on irrigated wheat was reported by $63 \%$ of farmers. In $198960 \%$ reportec losses of between a quarter and half their crop. In 1990 the severity of loss was less with 60\% reporting losses less than a quarter of their crop. A small proportion of farmers, 17\%, reporter locust damage, and again the severity of loss was less in 1990 than in 1990.

\subsection{Sunn pest infestation of rainfed wheat was severe with $63 \%$ of farmers reporting damage}


1989 all of whom estimated damage at between half and three quarters of their crop. The same overall number of farmers reported less severe damage in 1990 . 30\% of farmers reported damage to rainfed wheat by locusts, and the severity of damage was moderately less in 1989 compared to 1990.

2.25. $63 \%$ of farmers reported some damage to barley by Sunn pest, and the level of damage was the same in 1989 as in 1990 . 30\% reported locust damage to barley, the damage being marginally less in 1990 compared to 1989.

Province of Jowzjan, distrlct of Aqcha

2.26. $64 \%$ of farmers reported Sunn pest damage on irrigated wheat in 1989 with the majority reporting a quarter to half their crops lost, and some reporting $100 \%$ loss. The severity of loss was somewhat less in 1990. No locust damage was reported on this crop.

2.27. A quarter of farmers reported Sunn pest on rainfed wheat in both years, but the severity of loss was less in 1990 than in 1989. There were no reports of locusts.

2.28. Sunn pest infestation on barley was widespread with $95 \%$ and $87 \%$ of farmers reporting in 1989 and 1990 respectively. In 1989 over $80 \%$ of farmers reported losses of between a quarter and half their crop, but in 1990 losses were less severe with just under $80 \%$ reporting losses of up to a quarter of their crop. There were no reports of locust damage.

\section{Province of Jowzjan, distrlct of Mardyan}

2.29. All farmers reported damage by Sunn pest on irrigated wheat. In $198970 \%$ reported losses of between a quarter and half their crop, and $30 \%$ reported up to three quarters of their crop lost. These severe losses were moderately less in 1990 when, though all farmers were still affected, losses were less than a quarter of the crop. No locust damage was reported.

2.30. Sunn pest damage to rainfed wheat was less than to irrigated wheat. In 1989 half the farmers suffered losses, though these losses were high with $10 \%$ losing all their crop and the remaining $40 \%$ losing between half and three quarters of their crop. The effects were less in 1990 with $40 \%$ of farmers reporting losses of which the majority lost less than a quarter of their crop. There were no reports of locust damage.

2.31. Sunn pest damage on barley vias severe in 1989 all farmers affected of which $90 \%$ lost between a quarter and half their crop. In 1990 this figure was reduced to $70 \%$ with $30 \%$ of farmers unaffected. No losses due to locusts were reported.

\section{Province of Jowzjan, distrlct of Mengajek}

2.32. Again Sunn pest damage to irrigated wheat was severe with $96 \%$ of farmers reporting losses in 1989. Only $1 \%$ had losses of less than a quarter of their crop, and $19 \%$ lost at least half. In 1990 fewer farmers were affected, $72 \%$, and the majority lost less than a quarter of their crop. No locust damage was reported.

2.33.' None of the 75 farmers interviewed grew rainfed wheat.

2.34. Sunn pest damage to barley was widespread and moderately severe in 1989 but its effects 
were much less in 1990 . In $198991 \%$ of farmers were affected and $83 \%$ suffered between $25 \%$ and $50 \%$ loss of crop. In $199037 \%$ were affected of which the majority had losses of less than a quarter of their crop. No locust damage was reported.

\section{Province of Samangan, district of Samangan}

2.35. No Sunn pest damage to irrigated wheat was reported. One percent of farmers suffered locust damage, losing their entire crop. The rest were unaffected.

2.36. A few farmers reported Sunn pest damage to rainfed wheat, a total of $6 \%$ in 1989 and $16 \%$ in 1990. Locust damage to rainfed wheat affected over $40 \%$ of farmers in 1989 and $33 \%$ of farmers in 1990. Some suffered $100 \%$ crop loss, but the severity of loss was less in 1990, when the majority lost less than a quarter of their crop, than in 1989 when the majority lost between a quarter and half their crop.

2.37. Few farmers reported Sunn pest loss to barley in 1989 , with $7 \%$ of farmers reporting fairly small losses. In 1990 the situation is worse with 21 of farmers reporting losses. Locust damage to barley, on the other hand, is better in 1990, when $20 \%$ suffered damage, than in 1989 when the figure was $39 \%$. The severity of loss was roughly the same in each year.

\section{Province of Samangan, district of Darae Souf}

2.38. No Sunn pest or locust damage was reported on irrigated wheat.

2.39. Similarly, no Sunn pest damage was reported to rainfed wheat in 1989 , but in $199040 \%$ of farmers reported losses of up to a quarter of their crop and $5 \%$ reported losses over this level. This is an indication of how rapidly a farming community can be affected by Sunn pest. Locust damage to rainfed wheat affected $49 \%$ of farmers in 1989 and $32 \%$ in 1990.

2.40. The sudden influx of Sunn pest in 1990 affected the barley crop also. No farmer reported damage in 1989, but in $199037 \%$ reported damage. Locust damage, affecting $42 \%$ of farmers in 1989 and $30 \%$ in 1990, showed the same decrease as for rainfed wheat.

Province of Samangan, district of Khulm

2.41. Sunn pest damage to the irrigated wheat crop affected a few farmers - $16 \%$ in 1989 and $14 \%$ in 1990. In $19894 \%$ of those who grew the crop lost their entire crop to this cause. In $198922 \%$ of farmers reported losses due to locusts, of which half had losses of $100 \%$. In 1990 only $4 \%$ of farmers had losses and the level of these was less.

2.42. There were no losses to Sunn pest on rainfed wheat in 1989, but in $19904 \%$ of farmers reported some loss. 5\% reported losses due to locust in 1989 and $6 \%$ did so in 1990.

2.43. Sunn pest damage on barley affected $13 \%$ of farmers in 1989 and $18 \%$ in 1990 . On the other hand, locust damage was less severe in 1990 , when $4 \%$ of farmers reported moderate losses, compared to 1989 when $20 \%$ reported losses, including $3 \%$ who lost their entire crop.

Province of Samangan, district of Roye Doab

2.44. No losses were reported to irrigated wheat due to Sunn pest or locusts, though a reasonable 
sample of farmers growing this crop was interviewed - 55 farmers.

2.45. No Sunn pest was reported on rainfed wheat. But locust damage to this crop was severe, and $82 \%$ reported damage in 1989 and $78 \%$ in 1990 . In 1990 the severity of loss was marginally higher than in 1989.

2.46. No Sunn pest damage was reported on barley. But again locust damage was widespread, affecting $84 \%$ of farmers in 1989 and $75 \%$ in 1990.

Province of Baghlan, district of Nahrein

2.47. On irrigated wheat there were no reports of damage by Sunn pest or locusts.

2.48. On rainfed wheat also there was no damage by Sunn pest. But locust damage was reported by $12 \%$ of farmers in both years. In $19894 \%$ lost their entire crop, and in $19909 \%$ lost between half and three quarters.

2.49. Similarly for barley, there was no damage by Sunn pest reported. But $8 \%$ and $7 \%$ reported locust damage in 1989 and 1990 respectively.

Province of Baghlan, district of Khost Wa Fren

2.50. On irrigated wheat there were no reports of damage by Sunn pest or locusts.

2.51. On rainfed wheat also there was no damage by Sunn pest. Locust damage was moderately widespread, however, and the severity of losses often high. In $198948 \%$ of farmers reported losses, none of which was less than a quarter of the crop, and $25 \%$ lost $100 \%$. In 1990 the situation was more or less the same with $23 \%$ losing everything and again none losing less than a quarter of the crop.

2.52. Similarly for barley, there was no damage by Sunn pest reported. But $20 \%$ reported locust damage in each year, and the majority of these lost the entire crop.

Province of Kunduz, district of Kunduz

2.53. No damage was reported on any of the three crops by Sunn pest or locusts.

Province of Kunduz, district of Allabad

2.54. Ditto.

Province of Kunduz, district of Hazarat Imam

2.55. $9 \%$ reported some damage by Sunn pest, and $23 \%$ reported some damage by locusts to irrigated wheat in both years.

2.56. No farmer who grew rainfed wheat or barley was interviewed.

Province of Kunduz, district of Khanabad (shown in the annex tables as LJamabad) 
2.57. No damage by Sunn pest or locusts to irrigated wheat was reported.

2.58. $3 \%$ and $2 \%$ in 1989 and 1990 respectively reported some damage to rainfed wheat by Sunn pest. No damage was reported due to locusts.

2.59. No damage by Sunn pest or locusts to barley was reported.

Province of Kunduz, district of Archl

2.60. No damage by Sunn pest or locusts to irrigated or rainfed wheat was reported. Barley growers were not interviewed.

\section{Province of Kunduz, district of Char Dara}

2.61. $5 \%$ of farmers reported Sunn pest damage on irrigated wheat in 1989 but at the same time reported no damage in 1990. 20\% reported damage by locusts in 1989 and 5\% did so in 1990. The severity of losses in all cases was less than a quarter of the crop.

2.62. No damage was reported on rainfed wheat by either pest.

2.63. $2 \%$ reported Sunn pest damage to barley in 1989 but none did so in 1990 . Similarly, $8 \%$ reported locust damage in 1989 but none did so in 1990.

Province of Takhar, district of Taioqan

2.64. No insect damage reported on any crop.

Province of Takhar, district of Rustaq

2.65. No farmers growing irrigated wheat were interviewed, and no insect damage reported on any crop.

Province of Takhar, district of Khwajaghar

2.66. No insect damage reported on any crop.

Province of Takhar, district of Eshkamesh

2.67. No insect damage was reported on irrigated wheat. On rainfed wheat no Sunn pest was reported but $11 \%$ reported locust damage in 1989, some of it of a severe scale. No locust damage was reported in 1990. No damage was reported on barley.

Province of Takhar, district of Bangi

2.68. No insect damage reported on any crop.

Province of Badakhshan, district of Faizabad

2.69. No Sunn pest damage was reported on irrigated wheat. Locust damage was reported by $32 \%$ of farmers in both 1989 and 1990 with the severity of the losses rather worse in 1990, when half 
the farmers had losses over $50 \%$ and more than a quarter lost up to $100 \%$.

2.70. There was a similar, but much worse situation for rainfed wheat. No Sunn pest damage was reported, but all farmers reported locust damage in both years. In 1990 those reporting $100 \%$ loss - $20 \%$ - were almost double the level of the previous year.

2.71. Similarly for barley, no Sunn pest damage reported, but $100 \%$ reporting damage by locust, and again a greater level of loss in 1990 than in 1989, including $100 \%$ losses in both years.

\section{Province of Badakhshan, district of Ragh}

2.72. The sample was too low to be meaningful. Nevertheless, we see a similar pattern to Faizabad with no Sunn pest damage but "100\%" locust infestation.

\section{Province of Badakhshan, district of Sahre Bozurg}

2.73. No farmers growing irrigated wheat were interviewed. There were no reports of damage by Sunn pest to rainfed wheat, but locust damage was reported by $100 \%$ of farmers in both years, with the level of damage worse in 1990.

2.74. Farmers reported no damage by Sunn pest to barley, but $100 \%$ reported some damage by locusts in each year.

\section{Province of Badakhshan, dlstrict of Jurm}

2.75. Farmers reported no damage by Sunn pest to irrigated wheat, but $82 \%$ reported locust damage in each year with the level of damage considerably worse in 1990 than in 1989.

2.76. Similarly for rainfed wheat, farmers reported no Sunn pest damage, but locust damage was reported by $53 \%$ of farmers in both years with 1990 considerably worse.

2.77. Farmers reported no damage to barley from Sunn pest or locusts in either year.

\section{Province of Badakhshan, district of Baharak}

2.78. According to the survey $14 \%$ of farmers reported Sunn pest damage on irrigated wheat in both years, and in each case between a quarter and half the crop was lost. It is questionable whether the forms were filled correctly in this case, and we believe that it is unlikely that Sunn pest are a significant pest in Badakhshan. No grower of rainfed wheat was interviewed.

2.79. Over $\mathbf{8 0 \%}$ of farmers reported locust damage in both years, and the level of damage was marginally worse in 1990 .

\section{Province of Badakhshan, district of Eshkashem}

2.80. The sample was rather small. No grower of irrigated wheat was interviewed. On rainfed wheat no damage from Sunn pest was reported, but some damage by locusts was reported by $80 \%$ of farmers. Similarly with barley, there was no Sunn pest damage but $100 \%$ of farmers reported some damage by locusts. 
Province of Badakhshan, distrlct of Kesham

2.81. There were no reports of Sunn pest damage to irrigated wheat. But $68 \%$ of farmers reported damage by locusts in both years, the level of which was marginally worse in 1990.

2.82. On rainfed wheat $1 \%$ of farmers reported the minimum level of damage by Sunn pest in both years. Locust damage affected $99 \%$ of farmers in both years with the level of damage moderately worse in 1990.

2.83. There was no Sunn pest damage on barley, but $23 \%$ of farmers reported some damage by locusts in both years.

Province of Herat, district of Enjeel

2.84. There were no reports of any damage to irrigated wheat and barley, and no growers of rainfed wheat were interviewed.

Province of Herat, district of Gozorah

2.85. $7 \%$ of farmers reported Sunn pest damage to irrigated wheat in 1989 rising to $9 \%$ in $1990.5 \%$ reported locust damage falling to $2 \%$ in 1990 . 9\% reported Sunn pest damage to rainfed wheat in both years, with the level of losses worse in 1989 than in $1990.4 \%$ reported locust damage in 1989 , rising to $7 \%$ in 1990.

2.86. Similarly for barley, $9 \%$ reported Sunn pest damage in both years but the level of losses was somewhat worse in 1990. 2\% reported locust damage in 1989 rising to 9\% in 1990.

Province of Herat, distrlct of Pashtoon Zarghune

2.87. No farmer reported Sunn pest or locust damage on irrigated or rainfed wheat, or barley.

Province of Herat, district of Obey

2.88. Ditto for irrigated wheat and barley, and no growers of rainfed wheat were interviewed.

Province of Herat, district of Zendajan

2.89. Ditto.

Province of Herat, district of Adreskan

2.90. Ditto. 


\section{CHAPTER THREE. GENERAL AGRICULTURAL SITUATION}

3.1. Farmers in Afghanistan have many problems of which the outbreaks of Sunn pest and locust are only two. The question therefore arises, "In relation to all his other problems, especially the direct effects of war, but also those other perennial problems such as rainfall, irrigation water, other farm inputs including labour, and other crop pests and diseases, what is the magnitude of the present problem of Sunn pest and locusts?".

3.2. Clearly, a survey team specialised in insect damage assessment might have received or recorded a biased answer. This being so or not, unbiased information was already available from the ASA's 1989 National Survey of agriculture, and is presented for the relevant provinces and districts in Tables 27 to 29, headed "Constraints to Crop Production, Problems as Perceived by Farmers". This set of questions was designed before the problem of Sunn pest and locusts was known. It was designed in order to rank problems against each other. Although this set of information has the advantage of being unbiased, it also means that there is not a perfect match of districts between the two surveys. Some districts appear in both sets of tables and some appear only in one. However, this allows an intuitive projection of the information in these three tables to be made, if certain districts do not appear in the Insect Damage Survey but do in the National Survey.

3.3. Three columns are of particular importance: "Crop Protection", "Insects", and "Crop Diseases". If farmers identify the need for crop protection, then they could mean crop protection (almost always as chemical inputs) against insects or crop diseases. If the column "Crop Diseases" has a low score and the columns "Insects" and "Crop Protection" have a high score, then the respondent's meaning is clear - he wants assistance with insect control. Furthermore, if those two coiumns have a score which is higher than other columns, we know that it is his biggest. problem, at least for that year. Finally, by looking at the scores for neighbouring districts and provinces, one can obtain an indication of whether, for example, the insect problem was greater than the rainfall problem because it was a wet year, or whether it was a normal or dry year and still the insect problem was seen to be greater.

3.4. The provinces of Baghlan, Takhar, Kunduz, and Badakhshan in Table 27 are unremarkable and identify the usual main problems - war effects, rainfall, and irrigation water, as well as some other local problems. (Except for Badakhshan ${ }^{1}$ ), they support what the results of the Insect Damage Survey shows - that the problem of insects is not great in relation to other problems in these provinces.

3.5. In Table 28, the picture is quite different. In Faryab, the values in the column "Insects" exceed all others, including rainfall ${ }^{2}$ and war effects in all districts except one, Shirin Tagab. The values

\footnotetext{
1. We conclude that the ASA National Survey information showing that farmers do not rank "insects" as a big prolem is incorrect. Information from a number of independent sources as well as from the IDS show that locusts in particular have indeed been serious in many districts of Badakhshan in 1990, especially Dareen, Kesham and Yaftal. Moderate outbreaks have also been reported in Jurm, Ragh, Baharak, Argu and Kheskam.
}

2. Over three quarters of Faryab farmers rely soley on rainfed farming, and almost all the rest have farms which on average have three times as much rainfed land as irrigated land - see ASA's Third Report, Crops and Yields, August, 1989. 
in the column headed "Crop Protection" are also high, while at the same time the values in column headed "Crop Disease" are only moderate. The message that farmers rank ins damage as their biggest problem is a clear one. Taking the province as a whole in relatio other provinces, we can say that this table shows us that Faryab, in the perception of farmers the most seriously affected of all provinces.

3.6. For Balkh the picture is not quite so clear. Farmers have many problems of which insects only one, and irrigation is clearly the most important. In the district of Chemtal irrigation insects have almost the same values and far exceed all other problems. In all other distr insects seem, in the perception of farmers, to be just another problem to cope with.

3.7. In Samangan where the majority of farmers grow mainly rainfed crops, rainfall is predominant problem, and war effects are also seen as serious, but after these insects are biggest farming problem. In two of the four districts insects are the second problem a rainfall.

3.8. On the whole Jowzjan has moderate values in the "insects" column. Improved seed, fertili farm power, and of course irrigation water, are generally seen as greater problems. The val for the districts of Aqcha and Sang Charak are more or less in line with the results of the In Damage Survey though we would expect a higher value for Aqcha.

3.9. For Badghis, the values under the "insects" column are in all districts much higher than other, and the values for "crop protection" are also moderately high. Clearly, farmers in Bads see this problem as greater than all others and this is borne out amply by the IDS results.

1. In contrast to Faryab, about $70 \%$ of farmers in Balkh only grow irrigated crops. 


\section{CHAPTER FOUR. SUMMARY OF PROJECTS ARISING FROM THE SURVEY}

4.1. A number of projects have been designed by the ASA in collaboration with UNDP, the main funder of the NACCP last year and again in 1990, and with the several NGOs who will implement them. The projects have been designed on the basis of the 1989 NACPP experience, and of the results of this Insect Damage Survey.

4.2. Briefly, the project proposals now being finalised are, like last year, in three main parts: training, implementation, and delivery of insecticide and sprayers. There are, however, a number of differences compared to last year.

4.3. First, whereas last year all the training of field workers took place in Peshawar, this year 30 Superviser/Trainers will be trained in Peshawar and then be sent to the affected provinces where they will train a further 120 field staff at 17 training sites before March, the beginning of the spraying season.

4.4. Second, last year's experience taught that the availability of water for mixing with conventional insecticides in the rainfed areas was often a problem, and that normal volume hand-powered and motorised knapsack sprayers were not popular. This year ultra-low volume (ULV) sprayers will be used which require little water and cover a large area with a relatively small amount of insecticide.

4.5. Third, two insecticides will be used, both of which are safer to use and safe for the environment. The objective last year was to use BHC because it was there and the farmers were used to it, but to introduce them to better and safer insecticides at the same time. Now the projects will promote only the safer insecticides, one tested last year - Dimethoate - for use in conventional sprayers, and one for use in the ULV sprayers - Sumicombi-alpha.

4.6. Fourth, for logistical reasons the implementing NGOs will concern themselves only with training and field operations, while UNOCA will be responsible for the delivery of insecticide and sprayers.

4.7. Finally and most significant, whereas last year the programme consisted of a series of pilot projects on relatively small areas which were designed to find ways of dealing with the problem, this year the proposed project covers about two and a half a million jeribs $(500,000$ hectares) of cultivated land across the whole of Northern Afghanistan. The Swedish Committee part of the project alone is designed to directly benefit over 60,000 farm families, and indirectly over one and a half million people.

4.8. Present intentions are that four NGOs will implement the project: the Swedish Committee, the Nonwegian Committee, Afghanaid, and the Danish Committee. The SCA will take the two most seriously affected provinces, Faryab and Badghis, as well as Herat, Jowzjan, Balkh, and part of Samangan. The NCA will take Badakhshan, Afghanaid will take Takhar and Kunduz, and DACAAR will take part of Samangan and Baghlan. Training of all 30 Superviser/Trainers, including those from the other NGOs, will be done by the SCA. It is proposed that UNOCA will deliver the insecticides and sprayers to 17 sites in Northern Afghanistan. Present indications are that, through UNOCA, the Government of Japan will supply the Sumicombi-alpha, the British Government will supply the sprayers, and a third country will supply the dimethoate. 
4.9. Blue Silver, the new rainfed wheat variety identified and promoted by the SCA, which because of its early maturity can avoid the worst attacks of Sunn pest, and which was part of last year's NACPP, is not part of this particular programme but is included under a separate Seed Programme implemented by FAO, the SCA and several other NGOs. Blue Silver's performance in the 1989/90 cropping season was in almost all cases superior in terms of yield and Sunn pest avoidance (earliness of maturity). 
1. Tables 1 to 26 on the following pages are fairly self-explanatory up to the right-most columns headed "Percentage" under the blocks headed "1989" and "1990', which this footnote explains, as follows. The row "0 1-25 26-50" etc. refers to percentage lose of crop. The block of figures under that, and the "percentage" in the block title, refers to the percentage of farmers in each category Thus in Table 1, the column headed "Percentage" under the block headed "1989" begins with the row "19 3843 " and means "19\% of farmers had zero loss, $38 \%$ of farmers had losses between $1 \%$ and $25 \%$ of their crop, and $43 \%$ lost between $26 \%$ and $50 \%$ of their crop". The total is $100 \%$ and refers to all farmers growing that crop, in this example rainfed wheat. The top half of the page refers to losses due to Sunn pest, and the lower half of the page refere to losses due to locust. These two halves are split again into "farmers assessing their own damage" and "farmere assessing village damage". 
Table 1. Badghis

Rainfed Wheat - Sunn pest and Locust damage

1989

\begin{tabular}{|c|c|c|c|c|c|}
\hline District & No of & $\frac{\text { No of }}{\text { Farmers }}$ & $\frac{\text { no growing }}{\text { crop }}$ & $\frac{x \text { growing }}{\text { crop }}$ & $\begin{array}{l}\text { percentage damage } \\
1-25 \quad 26-50 \quad 51-75 \\
76-100\end{array}$ \\
\hline
\end{tabular}
Sunnpest

Percentage of Farmers assessing Own Damage

$\begin{array}{lrrr}\text { Qala Nau } & 20 & 100 & 77 \\ \text { Khuske Kohna } & 9 & 40 & 34 \\ \text { Qades } & 21 & 105 & 85\end{array}$

Percentage of Farmers assessing Village Damage

Qala Nau

Khuske Kohna

20
9
21

100
40
105

77
34
85

Locusts

Percentage of Farmers assessing Own Damage

Qala Nau

Khuske Kohna

$\begin{array}{rrr}20 & 100 & 77 \\ 9 & 40 & 34 \\ 21 & 105 & 85\end{array}$

77
85
81

77
85
81

1938

1345

43
43

43
19

$\begin{array}{llllll}77 & 19 & 37 & 43 & - & - \\ 85 & 13 & 43 & 43 & 3 & - \\ 81 & 23 & 53 & 24 & - & -\end{array}$

Percentage of Farmers assessing Village Damage

Qalo Hau
Khuske Koh

Khuske
Qades

$\begin{array}{rr}20 & 100 \\ 9 & 40 \\ 21 & 105\end{array}$

77
34
85

$\begin{array}{llllll}77 & 19 & 56 & 25 & - & - \\ 85 & 13 & 48 & 40 & - & - \\ 81 & 15 & 38 & 45 & 2 & -\end{array}$

1990

$\frac{\text { no growing }}{\underline{\text { crop }}} \frac{x \text { growing }}{\underline{\text { crop }}} \quad \underline{1-25} \frac{\underline{\text { percentage damage }}}{\underline{26-50}} \underline{51-75} \quad \underline{76-100}$

$\begin{array}{llllrll}77 & 77 & 19 & 49 & 32 & - & - \\ 34 & 85 & 13 & 50 & 38 & - & - \\ 86 & 82 & 32 & 60 & 8 & - & -\end{array}$

$\begin{array}{lllllll}77 & 77 & 19 & 49 & 32 & - & - \\ 34 & 85 & 13 & 48 & 38 & 3 & - \\ 86 & 82 & 30 & 62 & 8 & - & -\end{array}$

$\begin{array}{lllllll}77 & 77 & 19 & 80 & 1 & - & - \\ 34 & 85 & 13 & 88 & - & - & - \\ 86 & 82 & 35 & 64 & 1 & - & -\end{array}$

$\begin{array}{lllllll}77 & 77 & 19 & 80 & 1 & - & - \\ 34 & 85 & 13 & 88 & - & - & - \\ 86 & 82 & 34 & 66 & - & - & -\end{array}$ 


\section{Table 4. Faryab}

Rainfed theat - Sumn pest and Locust damage

1989

Oistrict

No of No of

no growin

crop

$\underline{\text { growin }}$ cros percentage damage

\section{Sunnoest}

Percentage of Farmers assessing Own Oamage

Belcheragh

Shirin'Tagab

$\begin{array}{rrr}16 & 80 & 21 \\ 2 & 10 & 5 \\ 13 & 65 & 50\end{array}$

Percentage of Farmers assessing Village Oamage

Belcheragh

Shirin Tagab

Oarzab

$\begin{array}{rrr}16 & 80 & 21 \\ 2 & 10 & 5 \\ 13 & 65 & 50\end{array}$

Locusts

\section{Percentage of Farmers assessing Oun 0amage}

Belcheragh

Shirin Tagab

16
2
13

80
10
65

21
5
50

26
50
77

$\begin{array}{llllll}26 & 19 & 26 & 50 & 4 & 1 \\ 50 & 10 & 30 & 60 & - & - \\ 77 & 15 & 12 & 72 & - & -\end{array}$

15
4
48

$\begin{array}{rrrrrr}19 & 19 & 14 & 63 & 5 & - \\ 40 & 10 & 40 & 50 & - & - \\ 74 & 15 & 6 & 75 & 3 & -\end{array}$

Percentage of Farmers assessing Village Oamage

Belcheragh

Shirin Tagab

Darzab
16
2
13

80
10
65

21
5
50

26
50
77

$\begin{array}{ll}19 & 24 \\ 10 & 40\end{array}$

$\begin{array}{ll}10 & 40 \\ 15 & 15\end{array}$

$\begin{array}{rrr}55 & 3 & - \\ 40 & 10 & - \\ 69 & - & -\end{array}$

15
4
48

19
40
74

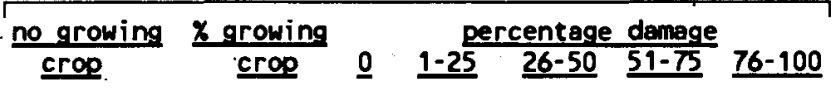

1990 


\section{Table 2. Badghis}

garley - Sunn pest and Locust damage

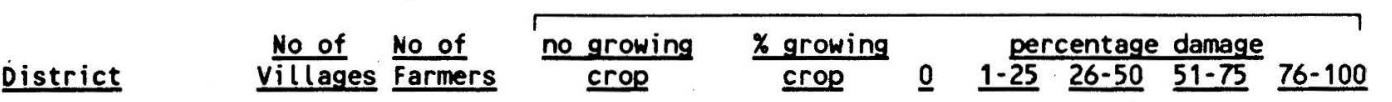

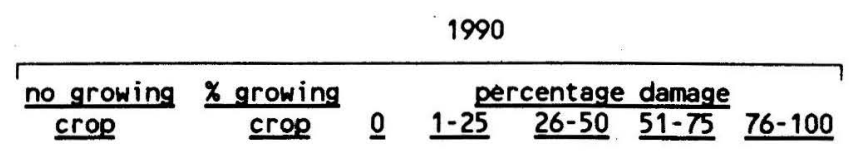

\section{Sunnpest}

Percentage of Farmers assessing Own Damage

$\begin{array}{lrrr}\text { Qala Nau } & 20 & 100 & 75 \\ \text { Khuske Kohna } & 9 & 40 & 33 \\ \text { Qades } & 21 & 105 & 67\end{array}$

Percentage of Farmers assessing Village Damage

\section{Qala Nau}

Khuske Kohna

$\begin{array}{rr}20 & 100 \\ 9 & 40 \\ 21 & 105\end{array}$

75
33
67

75
8
6

75
83
64

$100=$
$100=$
$100=$

Locusts

Percentage of Farmers assessing Own Damage

$\begin{array}{lrrr}\text { Qala Nau } & 20 & 100 & 75 \\ \text { Khuske Kohna } & 9 & 40 & 33 \\ \text { Qades } & 21 & 105 & 67\end{array}$

Percentage of Farmers assessing Village Damage

\section{Qala Nau}

Khuske Kohna

$\begin{array}{rrr}20 & 100 & 75 \\ 9 & 40 & 33 \\ 21 & 105 & 67\end{array}$

75
83
64

75
83
64

100

Qades

75
33
67

$\begin{array}{rrrrrr}75 & 19 & 39 & 42 & - & - \\ 83 & 13 & 5 & 80 & 3 & -\end{array}$

$\begin{array}{rrrrr}83 & 13 & 5 & 80 & 3 \\ 64 & 15 & 30 & 42 & 13\end{array}$

29

$\begin{array}{lllllll}62 & 62 & 100 & - & - & - & - \\ 49 & 73 & 100 & - & - & - & -\end{array}$

62
29

29

$\begin{array}{llll}62 & 62 & 23 & 77 \\ 29 & 73 & 13 & 88 \\ 49 & 47 & 39 & 50\end{array}$

$\begin{array}{rrrrrrr}62 & 62 & 20 & 79 & 1 & - & - \\ 29 & 73 & 13 & 88 & - & - & - \\ 49 & 47 & 38 & 50 & 11 & - & -\end{array}$


Table 1. Badghis

Rainfed Wheat - Sunn pest and Locust damage

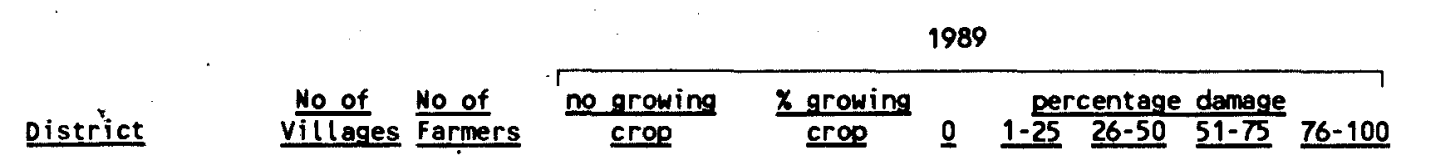

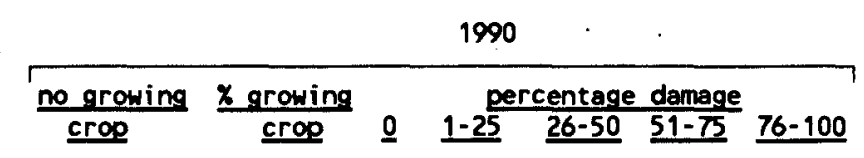

\section{Sunnoest}

Percentage of Farmers assessing Own Damage

Qala Nau

Khuske Kohna

$\begin{array}{rrr}20 & 100 & 77 \\ 9 & 40 & 34 \\ 21 & 105 & 85\end{array}$

77
85
81

1938

Qades

34
85

81

2358

43
43
19

Percentage of Farmers assessing Village Damage

\section{Qala Nau}

Khuske Kohne

$\begin{array}{rr}20 & 100 \\ 9 & 40\end{array}$

100
40
105
77
34
34
85

77
85

$\begin{array}{ll}19 & 37\end{array}$

Qades

85
81.

2353

Locusts

Percentage of Farmers assessing Own Damage

$\begin{array}{lrrr}\text { Qala Nau } & 20 & 100 & 77 \\ \text { Khuske Kohna } & 9 & 40 & 34 \\ \text { Qades } & 21 & 105 & 85\end{array}$

Percentage of Farmers assessing Village Damage

Oala Nau

Khuske Kohna

$\begin{array}{rr}20 & 100 \\ 9 & 40 \\ 21 & 105\end{array}$

77
34
85

77
85
81

$\begin{array}{ll}19 & 60 \\ 13 & 48\end{array}$

$15 \quad 41$

$\begin{array}{lll}21 & - & - \\ 40 & - & - \\ 43 & 1 & -\end{array}$

77

$\begin{array}{lll}77 & 19 & 80 \\ 85 & 13 & 88 \\ 82 & 35 & 64\end{array}$

Qades

$\begin{array}{llllll}77 & 19 & 56 & 25 & - & - \\ 85 & 13 & 48 & 40 & - & - \\ 81 & 15 & 38 & 45 & 2 & -\end{array}$

77
34
86

$\begin{array}{llllll}77 & 19 & 80 & 1 & - & - \\ 85 & 13 & 88 & - & - & - \\ 82 & 34 & 66 & - & - & -\end{array}$




\section{Table 5. Faryab}

Barley - Sunn pest and Locust damage

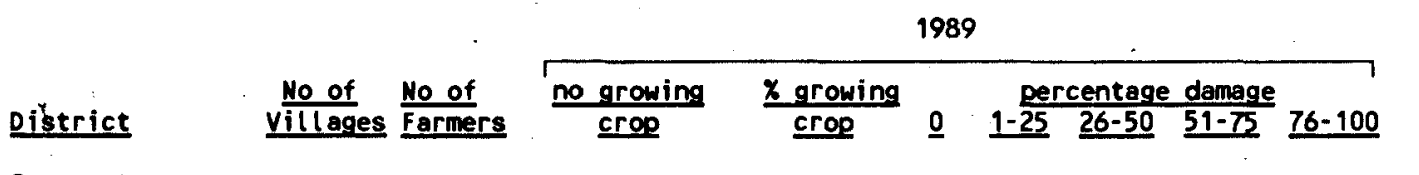

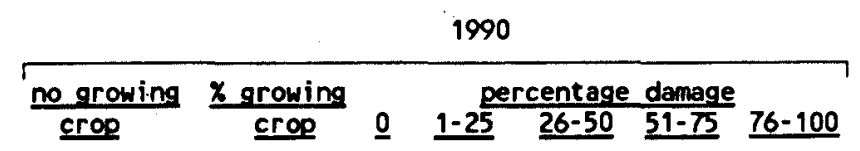

Sumpest

Percentage of Farmers assessing Own Damage

$\begin{array}{lrrr}\text { Belcheragh } & 16 & 80 & 51 \\ \text { Shirin Tagab } & 2 & 10 & 9 \\ \text { Darzab } & 13 & 65 & 42 \\ \text { Percentege of Farmers assessing Village } & \text { Demage }\end{array}$

Percentege of Farmers assessing Village Damage

Belcheragh

Shirin Tagab

$\begin{array}{rrr}16 & 80 & 51 \\ 2 & 10 & 9 \\ 13 & 65 & 42\end{array}$

$$
\begin{aligned}
& 64 \\
& 90 \\
& 65
\end{aligned}
$$

3068

1090

3466

Darzab

Locusts

Percentage of Farmers assessing Oun Danage

$\begin{array}{lrrr}\text { Belcheragh } & 16 & 80 & 51 \\ \text { Shirin Tagab } & 2 & 10 & 9 \\ \text { Darzab } & 13 & 65 & 42\end{array}$

Percentage of Farmers assessing Village Damage

Belcheragh

Shirin Tagab.

16
2
13

80
10
65

51
9
42

64
90
65

64
90
65

$\begin{array}{ll}24 & 76 \\ 10 & 90\end{array}$

2278

Darzab

$\begin{array}{rrr}16 & 80 & 51 \\ 2 & 10 & 9 \\ 13 & 65 & 42\end{array}$

$\begin{array}{lllll}40 & 24 & 36 & - \\ 10 & 60 & 30 & -\end{array}$

$\begin{array}{llll}38 & 29 & 32 & -\end{array}$

$\begin{array}{lllll}35 & 33 & 33 & - & - \\ 10 & 60 & 30 & - & - \\ 18 & 25 & 57 & - & -\end{array}$

53
9
42

$\begin{array}{lll}66 & 30 & 69 \\ 90 & 10 & 90 \\ 65 & 32 & 68\end{array}$

53

42

$\begin{array}{lll}66 & 24 & 76 \\ 90 & 10 & 90 \\ 65 & 22 & 78\end{array}$

$90 \quad 10 \quad 90$ 
Fäble 6. Jowzian

Irrigated theat - Sunn pest and Locust damage

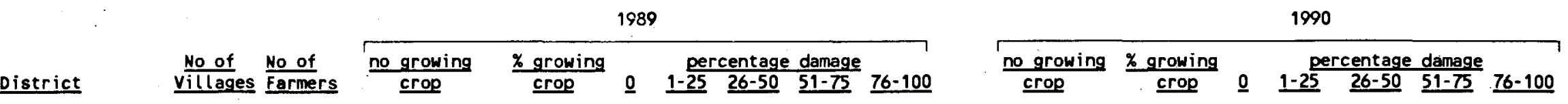

Sunnpest

Percentage of $F_{-i}$ mers assessing Own Damage

$\begin{array}{lrrr}\text { Sheberghan } & 1 & 5 & - \\ \text { Sang Charak } & 37 & 185 & 18 \\ \text { Sari Pul } & 6 & 40 & - \\ \text { Kohistanat } & 6 & 30 & 19 \\ \text { Aqcha } & 34 & 170 & 102 \\ \text { Mardyan } & 2 & 10 & 6 \\ \text { Mengajek } & 17 & 75 & 51\end{array}$

Percentage of Farmers assessing Village Damage

Sheberghan

Sang Charak

Sari Pul

Koh is tanat

Aqcha

Mardyan

Mengajek

$\begin{array}{rrr}1 & 5 & - \\ 37 & 185 & 18 \\ 6 & 40 & - \\ 6 & 30 & 19 \\ 34 & 170 & 102 \\ 2 & 10 & 6 \\ 17 & 75 & 51\end{array}$

10
63
60
60
68

$\begin{array}{rrrrr}- & - & - & - & - \\ 98 & 3 & 5 & 2 & 3 \\ 37 & - & - & 3 & - \\ 24 & 2 & 60 & 3 & - \\ - & - & 70 & 12 & 5 \\ 4 & 1 & 76 & 19 & -\end{array}$

16
19
103
6
48

$\begin{array}{rrrrrr}- & - & - & - & - & - \\ 9 & 88 & 4 & 4 & 3 & ? \\ 63 & - & - & - & - & - \\ 61 & 37 & 60 & 3 & - & - \\ 60 & 24 & 68 & 8 & 1 & - \\ 64 & 28 & 63 & 9 & - & -\end{array}$

Locusts

Percentage of Farmers assessing Own Damage

$\begin{array}{lrl}\text { Sheberghan } & 1 \\ \text { Sang Charak } & 37 & 185 \\ \text { Sari Pul } & 6 & \\ \text { Kohistanat } & 6 & \\ \text { Aqcha } & 34 & 170 \\ \text { Mardyan } & 2 & \\ \text { Mengajek } & 17\end{array}$

$\begin{array}{rr}5 & - \\ 185 & 18 \\ 40 & - \\ 30 & 19 \\ 170 & 102 \\ 10 & 6 \\ 75 & 51\end{array}$

$\begin{array}{rrrrrr}- & - & - & - & - & - \\ 10 & 88 & 2 & 4 & 3 & 3 \\ - & 98 & - & - & 3 & - \\ 63 & 37 & - & 47 & 17 & - \\ 60 & 22 & 2 & 49 & 22 & 5 \\ 60 & - & 10 & 70 & 20 & - \\ 68 & 4 & 1 & 73 & 21 & -\end{array}$

16
-
19
103
6
48

$\begin{array}{rrr}- & - & - \\ - & 88 & 4 \\ 63 & - & - \\ 61 & 23 & 47 \\ 60 & - & 65 \\ 64 & 28 & 63\end{array}$

Percentage of Farmers assessing Village Damage

Sheberghan

Sang Charak

Sari Pul

Koh istanat

Aqcha

Mardyan

Mengajek

$\begin{array}{rrr}1 & 5 & - \\ 37 & 185 & 18 \\ 6 & 40 & - \\ 6 & 30 & 19 \\ 34 & 170 & 102 \\ 2 & 10 & 6 \\ 17 & 75 & 51\end{array}$

$\begin{array}{cc}- & - \\ 10 & 97 \\ - & - \\ 63 & 83 \\ 60 & 100 \\ 60 & 100 \\ 68 & 100\end{array}$

$\begin{array}{ccc}- & - & - \\ 10 & 97 & - \\ - & - & - \\ 63 & 83 & - \\ 60 & 100 & - \\ 60 & 100 & - \\ 68 & 100 & -\end{array}$

-
16
19
103
6
48

$\begin{array}{rrrrrr}- & - & - & - & - & - \\ 9 & 97 & - & 3 & - & - \\ 63 & - & - & - & - & - \\ 63 & 100 & 17 & - & - & - \\ 60 & 100 & - & - & - & - \\ 64 & 100 & - & - & - & -\end{array}$

\begin{tabular}{rrr}
\hline & - & - \\
- & 97 & - \\
63 & - & - \\
61 & 100 & 17 \\
60 & 100 & - \\
64 & 100 & -
\end{tabular}




\section{Table 7. Jowzian}

Rainfed theat - Sum pest and Locust damage

\begin{tabular}{|c|c|c|c|}
\hline & & \multicolumn{2}{|c|}{1989} \\
\hline & No of & no growing & $\underline{\boldsymbol{x} \text { growing }}$ \\
\hline
\end{tabular}

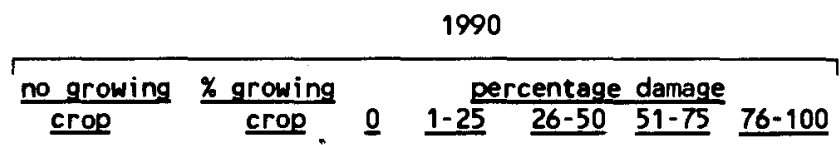

\section{Sunnpest}

Percentage of Farmers assessing Own Damage

$\begin{array}{lrrr}\text { Sheberghan } & 1 & 5 & 4 \\ \text { Sang Charak } & 37 & 185 & 155 \\ \text { Sari Pul } & 6 & 40 & 27 \\ \text { Kohistanat } & 6 & 30 & 22 \\ \text { Aqcha } & 34 & 170 & 28 \\ \text { Mardyan } & 2 & 10 & 3 \\ \text { Mengajek } & 17 & 75 & -\end{array}$

Percentage of Farmers assessing Village Damage

$\begin{array}{lrrr}\text { Sheberghan } & 1 & 5 & 4 \\ \text { Sang Charak } & 37 & 185 & 155 \\ \text { Sari Pul } & 6 & 40 & 27 \\ \text { Kohistanat } & 6 & 30 & 22 \\ \text { Aqcha } & 34 & 170 & 28 \\ \text { Mardyan } & 2 & 10 & 3 \\ \text { Mengajek } & 17 & 75 & -\end{array}$

$\begin{array}{rrrrrr}80 & - & 100 & - & - & - \\ 84 & 6 & 5 & 49 & 15 & 25 \\ 68 & 3 & - & 8 & 8 & 83 \\ 73 & 37 & - & - & 63 & - \\ 17 & 74 & 1 & 17 & 8 & 1 \\ 30 & 50 & - & - & 40 & 10 \\ - & - & - & - & - & -\end{array}$

$\begin{array}{rrrrrrr}4 & 80 & - & 100 & - & - & - \\ 143 & 77 & 6 & 36 & 25 & 30 & 3 \\ 30 & 75 & 3 & 10 & 5 & 83 & - \\ 18 & 60 & 37 & 27 & 37 & - & - \\ 23 & 14 & 74 & 24 & 3 & - & - \\ - & - & 60 & 30 & 10 & - & - \\ - & - & - & - & - & - & -\end{array}$

Locusts

Percentage of Farmers assessing Own Damage

$\begin{array}{lrrr}\text { Sheberghan } & 1 & 5 & 4 \\ \text { Sang Charak } & 37 & 185 & 155 \\ \text { Sari Pul } & 6 & 40 & 27 \\ \text { Kohistanat } & 6 & 30 & 22 \\ \text { Aqcha } & 34 & 170 & 28 \\ \text { Mardyan } & 2 & 10 & 3 \\ \text { Menga jek } & 17 & 75 & -\end{array}$

Percentage of Farmers assessing Village Damage

$\begin{array}{lrrrrrr}\text { Sheberghan } & 1 & 5 & 4 & 80 & -100 \\ \text { Sang Charak } & 37 & 185 & 155 & 84 & 43 & 37 \\ \text { Sari Pul } & 6 & 40 & 27 & 68 & 50 & 13 \\ \text { Kohistanat } & 6 & 30 & 22 & 73 & 70 & - \\ \text { Aqcha } & 34 & 170 & 28 & 17 & 100 & - \\ \text { Mardyan } & 2 & 10 & 3 & 30 & 100 & - \\ \text { Mengajek } & 17 & 75 & - & - & -\end{array}$

$\begin{array}{rrrrrr}80 & - & - & 100 & - & - \\ 84 & 5 & 1 & 30 & 34 & 30 \\ 68 & 5 & - & 3 & 10 & 83 \\ 73 & 37 & - & - & 63 & - \\ 17 & 74 & - & 14 & 11 & 2 \\ 30 & 50 & - & 10 & 30 & 10 \\ - & - & - & - & - & -\end{array}$

$\begin{array}{rrrr}4 & 80 & - & 80 \\ 143 & 77 & 5 & 11 \\ 30 & 75 & 5 & 8 \\ 18 & 60 & 37 & 27 \\ 23 & 14 & 74 & 25 \\ - & - & 60 & 30 \\ - & - & - & -\end{array}$

$\begin{array}{rrr}80 & 100 & - \\ 84 & 44 & 47 \\ 68 & 50 & 13 \\ 73 & 70 & - \\ 17 & 100 & - \\ 30 & 100 & - \\ - & - & -\end{array}$

$\begin{array}{rrr}- & - & - \\ 9 & - & - \\ 13 & - & 13 \\ - & - & - \\ - & - & - \\ - & - & -\end{array}$

4
143
30
18
23
-
-

$\begin{array}{rrrrrr}80 & 100 & - & - & - & - \\ 77 & 44 & 35 & 22 & - & - \\ 75 & 50 & 38 & - & 13 & - \\ 60 & 70 & 13 & 17 & - & - \\ 14 & 100 & - & - & - & - \\ - & - & - & - & - & - \\ - & - & - & - & - & -\end{array}$

\section{Mengajek \\ Sheberghan \\ Sari Pul \\ Koh istanat}


Table 8. Jowzian

Barley - Sunn pest and Locust damage

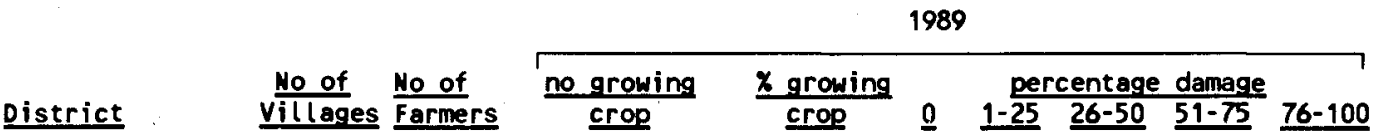

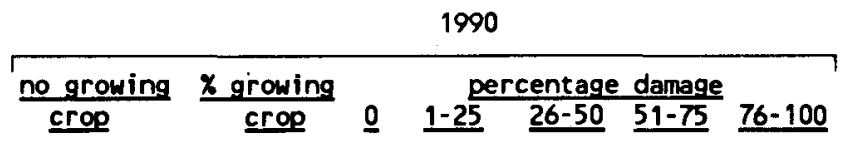

Sunnpest

Percentage of Farmers assessing Own Damage

$\begin{array}{lrrr}\text { Sheberghan } & 1 & 5 & - \\ \text { Sang Charak } & 37 & 185 & 106 \\ \text { Sari Pul } & 6 & 40 & 23 \\ \text { Kohistanat } & 6 & 30 & 26 \\ \text { Aqcha } & 34 & 170 & 115 \\ \text { Mardyan } & 2 & 10 & 6 \\ \text { Mengajek } & 17 & 75 & 57\end{array}$

Percentage of Farmers assessing Village Damage

$\begin{array}{lrrr}\text { Sheberghan } & 1 & 5 & - \\ \text { Sang Charak } & 37 & 185 & 106 \\ \text { Sari Pul } & 6 & 40 & 23 \\ \text { Kohistanat } & 6 & 30 & 26 \\ \text { Aqcha } & 34 & 170 & 115 \\ \text { Mardyan } & 2 & 10 & 6 \\ \text { Mengajek } & 17 & 75 & 57\end{array}$

$\begin{array}{rrr}57 & 75 & 4 \\ 58 & 28 & - \\ 87 & 37 & 63 \\ 68 & 5 & 11 \\ 60 & - & 10 \\ 76 & 9 & 8\end{array}$

$\begin{array}{rrr}- & - & - \\ 8 & 8 & 6 \\ 3 & 20 & 50 \\ 81 & - & - \\ 90 & 2 & - \\ 83 & - & -\end{array}$

110
22
23
110
6
47

$\begin{array}{rrrrrr}- & - & - & - & - & - \\ 60 & 75 & 5 & 10 & 10 & 1 \\ 55 & 28 & 38 & - & 23 & 13 \\ 77 & 37 & 63 & - & - & - \\ 65 & 12 & 79 & 8 & - & - \\ 60 & 30 & 70 & - & - & - \\ 63 & 63 & 28 & 9 & - & -\end{array}$

Locusts

Percentage of Farmers assessing Oun Damage

$\begin{array}{lrrr}\text { Sheberghan } & 1 & 5 & - \\ \text { Sang Charak } & 37 & 185 & 106 \\ \text { Sari Pul } & 6 & 40 & 23 \\ \text { Kohistanat } & 6 & 30 & 26 \\ \text { Aqcha } & 34 & 170 & 115 \\ \text { Mardyan } & 2 & 10 & 6 \\ \text { Mengajek } & 17 & 75 & 57\end{array}$

Mengojek

$\begin{array}{rrrrrr}57 & - & - & - & - & - \\ 58 & 75 & 2 & 7 & 6 & 10 \\ 87 & 28 & 3 & 3 & 25 & 43 \\ 68 & 37 & 53 & 10 & - & - \\ 60 & 4 & 11 & 82 & 2 & 1 \\ 76 & - & - & 100 & - & -\end{array}$

110
22
23
110
6
47

$\begin{array}{rrrrrr}- & - & - & - & - & - \\ 60 & 75 & 3 & 9 & 13 & 1 \\ 55 & 28 & 43 & - & 18 & 13 \\ 77 & 37 & 63 & - & - & - \\ 65 & 11 & 82 & 6 & 1 & - \\ 60 & 30 & 70 & - & - & - \\ 63 & 61 & 28 & 11 & - & -\end{array}$

Percentage of Farmers assessing Village Damage

$\begin{array}{lrrrrrrr}\text { Sheberghan } & 1 & 5 & - & - & - \\ \text { Sang Charak } & 37 & 185 & 106 & 57 & 86 & 10 \\ \text { Sari Pul } & 6 & 40 & 23 & 58 & 63 & - \\ \text { Kohistanat } & 6 & 30 & 26 & 87 & 70 & 13 \\ \text { Aqcha } & 34 & 170 & 115 & 68 & 100 & - \\ \text { Mardyan } & 2 & 10 & 6 & 60 & 100 & - \\ \text { Menga jek } & 17 & 75 & 57 & 76 & 100\end{array}$

Menga jek

$\begin{array}{rr}106 & 57 \\ 23 & 58 \\ 26 & 87 \\ 115 & 68 \\ 6 & 60 \\ 57 & 76\end{array}$

$\begin{array}{rrrrrr}57 & - & - & - & - & - \\ 58 & 86 & 10 & 1 & 3 & - \\ 87 & 75 & - & 13 & 13 & - \\ 68 & 100 & 13 & 17 & - & - \\ 60 & 100 & - & - & - & - \\ 76 & 100 & - & - & - & -\end{array}$

110
22
23
110
6
47

$\begin{array}{rrrrrr}- & - & - & - & - & - \\ 60 & 86 & 8 & 3 & 3 & - \\ 55 & 75 & 10 & 13 & 3 & - \\ 77 & 70 & 30 & - & - & - \\ 65 & 100 & - & - & - & - \\ 60 & 100 & - & - & - & - \\ 63 & 100 & - & - & - & -\end{array}$

17


Table 9. Samangan

Irrigated theat - Sunn pest and Locust damage

1989

District $\frac{\text { No of }}{\underline{i l l \text { ages }}} \frac{\text { No of }}{\text { Farmers }} \frac{\text { no growing }}{\underline{\text { crop }}} \frac{x \text { growing }}{\text { crop }} \underline{0} \frac{1-\frac{\text { percentage damage }}{25}}{26-50} \underline{51-75} \underline{76-100}$

Sunnpest

Percentage of Farmers assessing Own Damage

\section{Samangan}

Darae Souf

Khulm

Roye Doab

$\begin{array}{rrr}25 & 125 & 22 \\ 13 & 65 & 1 \\ 14 & 70 & 54 \\ 16 & 79 & 55\end{array}$

18
2
77
70

100
100
84
100

Percentage of Farmers assessing Village Damage

\section{Samangan}

Darae Souf

Khulm

Roye Doab

$\begin{array}{rr}25 & 125 \\ 13 & 65 \\ 14 & 70 \\ 16 & 79\end{array}$

125
65
70
79

22
1
54
55

18
2
77
70

Locusts

Percentage of Farmers assessing Own Damage

\section{Semangan}

Darae Souf

Khulm

Roye Doab

$\begin{array}{ll}25 & 125 \\ 13 & 65 \\ 14 & 70 \\ 16 & 79\end{array}$

22
1
54
55

Percentage of Farmers assessing Village Damage

Samangan

Darae Souf

Khulm

Roye Dosb

$\begin{array}{rrr}25 & 125 & 22 \\ 13 & 65 & 1 \\ 14 & 70 & 54 \\ 16 & 79 & 55\end{array}$

22
1
54
55

5

18
2
77
70

$\begin{array}{rrrrr}99 & - & - & - & 1 \\ 100 & - & - & - & - \\ 77 & 4 & 7 & - & 11 \\ 100 & - & - & - & -\end{array}$

23
1
53
53

$\begin{array}{rrrrrr}18 & 99 & - & 1 & - & - \\ 2 & 100 & - & - & - & - \\ 76 & 96 & 1 & 3 & - & - \\ 67 & 100 & - & - & - & -\end{array}$

18
27
70

$\begin{array}{rrrrrr}18 & 98 & 1 & 1 & - & - \\ 2 & 100 & - & - & - & - \\ 77 & 67 & 11 & 20 & 1 & - \\ 0 & 100 & - & - & - & -\end{array}$

23
1
53
53

$\begin{array}{rrrrrr}18 & 99 & - & 1 & - & - \\ 2 & 100 & - & - & - & - \\ 76 & 89 & 9 & 3 & - & - \\ 67 & 100 & - & - & - & -\end{array}$

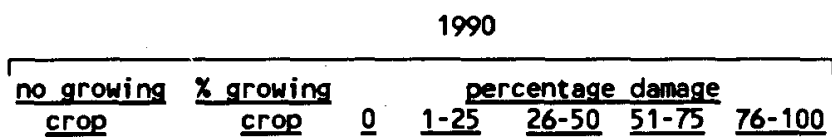

23
1
53
53

$\begin{array}{rrrrrr}18 & 100 & - & - & - & - \\ 2 & 100 & - & - & - & - \\ 76 & 86 & 7 & 7 & - & - \\ 67 & 100 & - & - & - & -\end{array}$

23
1
53
53

$\begin{array}{rrr}18 & 100 & - \\ 2 & 100 & - \\ 76 & 61 & 33 \\ 67 & 100 & -\end{array}$


Table 10. Samangan

Rainfed theat - Sunn pest and Locust damage

District $\frac{\text { No of }}{\text { villages }} \frac{\text { No of }}{\text { Farmers }} \frac{1989}{\text { no growing }} \frac{\text { x growing }}{\underline{\text { crop }}} \underline{0} \frac{\text { percentage damage }}{1-\frac{25}{26-50} \underline{51-75}} \underline{76-100}$

Sunnest

Percentage of Farmers assessing Own Damage

$\begin{array}{lrrr}\text { Samangan } & 25 & 125 & 108 \\ \text { Darae Souf } & 13 & 65 & 57 \\ \text { Khulm } & 14 & 70 & \\ \text { Roye Doab } & 16 & 79 & 32\end{array}$

Roye Doab

108
57
6
32

86
88
4

$\begin{array}{lr}86 & 94 \\ 9 & 100 \\ 1 & 100\end{array}$

$\begin{array}{rrr}94 & 3 & 2 \\ 100 & - & - \\ 100 & - & - \\ 100 & - & -\end{array}$

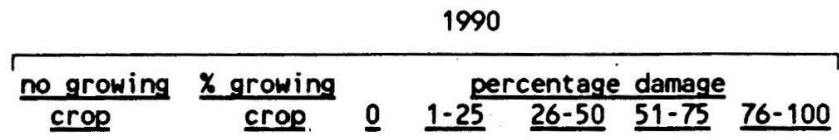

Percentage of Farmers assessing Village Damage

$\begin{array}{lrrr}\text { Samangan } & 25 & 125 & 108 \\ \text { Darae Souf } & 13 & 65 & 57 \\ \text { Khulm } & 14 & 70 & 6 \\ \text { Roye Doab } & 16 & 79 & 32\end{array}$

Roye Doab

$\begin{array}{rrr}86 & 94 & 6 \\ 88 & 100 & - \\ 9 & 100 & - \\ 41 & 100\end{array}$

Locusts

Percentage of Farmers assessing Own Damage

$\begin{array}{lrrr}\text { Samangan } & 25 & 125 & 108 \\ \text { Darae Souf } & 13 & 65 & 57 \\ \text { Khulm } & 14 & 70 & 6 \\ \text { Roye Doab } & 16 & 79 & 32\end{array}$

Percentage of Farmers assessing Village Damage

\section{Samangan}

Darae Souf

Khulm

$\begin{array}{rrr}25 & 125 & 108 \\ 13 & 65 & 57 \\ 14 & 70 & 6 \\ 16 & 79 & 32\end{array}$

Roye Doab

$\begin{array}{rrr}86 & 59 & 8 \\ 88 & 51 & 15 \\ 9 & 94 & - \\ 41 & 18 & 22\end{array}$

$\begin{array}{rrr}25 & 2 & 6 \\ 34 & - & - \\ 4 & 1 & - \\ 58 & 3 & -\end{array}$

$\begin{array}{rrrr}86 & 47 & 13 & 38 \\ 88 & 46 & 9 & 45 \\ 9 & 94 & - & \\ 41 & 13 & 14 & 73\end{array}$

$\begin{array}{ll}94 & 14\end{array}$

$\begin{array}{rrr}38 & 2 & - \\ 45 & - & - \\ 4 & 1 & -\end{array}$

105
56
5
26

$\begin{array}{rrrrrr}84 & 74 & 23 & 3 & - & - \\ 86 & 60 & 35 & 5 & - & - \\ 7 & 96 & 4 & - & - & - \\ 33 & 100 & - & - & - & -\end{array}$

$\begin{array}{rrrrrr}84 & 70 & 26 & 3 & - & - \\ 86 & 58 & 42 & - & - & - \\ 7 & 96 & 4 & - & - & - \\ 33 & 100 & - & - & - & -\end{array}$

105
56
5
26

$\begin{array}{rrrrrr}84 & 63 & 26 & 10 & 1 & - \\ 86 & 66 & 20 & 14 & - & - \\ 7 & 94 & 4 & - & 1 & - \\ 33 & 18 & 14 & 68 & - & -\end{array}$


Table 11. Samangan

Barley - Sunn pest and Locust damage

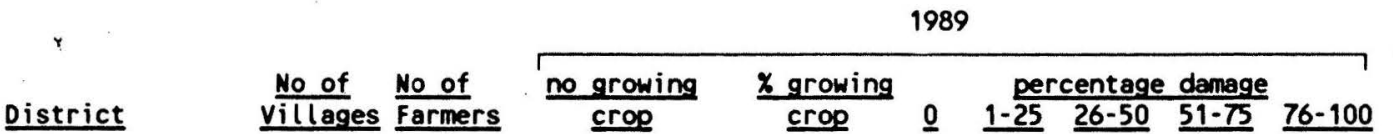

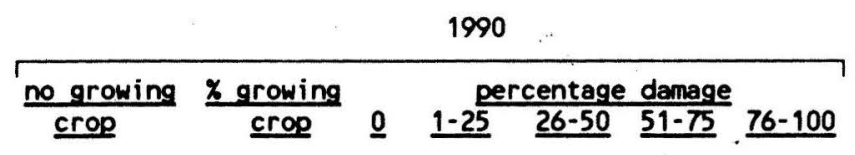

\section{Sunnpest}

Percentage of Farmers assessing Own Damage

$\begin{array}{lrrr}\text { Samangan } & 25 & 125 & 87 \\ \text { Darae Souf } & 13 & 65 & 52 \\ \text { Khulm } & 14 & 70 & 42 \\ \text { Roye Doab } & 16 & 79 & 66\end{array}$

Percentage of Farmers assessing Village Damage

Samangan

Darae Souf

Khulm

Roye Doab

$\begin{array}{lrl}25 & 125 & 87 \\ 13 & 65 & 52 \\ 14 & 70 & 42 \\ 16 & 79 & 66\end{array}$

$\begin{array}{rrr}70 & 94 & 5 \\ 80 & 100 & - \\ 60 & 86 & 7 \\ 84 & 100 & \end{array}$

77
49
24
66

$\begin{array}{rrrrrr}62 & 79 & 19 & 2 & - & - \\ 75 & 63 & 37 & - & - & - \\ 34 & 81 & 14 & 4 & - & - \\ 84 & 100 & - & - & - & -\end{array}$

Locusts

Percentage of Farmers assessing Oun Damage

$\begin{array}{lrrr}\text { Samangan } & 25 & 125 & 87 \\ \text { Darae Souf } & 13 & 65 & 52 \\ \text { Khulm } & 14 & 70 & 42 \\ \text { Roye Doab } & 16 & 79 & 66 \\ \text { Percentage of Farmers assessing Village } & \end{array}$

$\begin{array}{rrrrrr}70 & 96 & 4 & - & - & - \\ 80 & 100 & 5 & - & - & - \\ 60 & 79 & 7 & 14 & - & - \\ 84 & 100 & - & - & - & -\end{array}$

77
49
24
66

$\begin{array}{rrrrrr}62 & 78 & 22 & - & - & - \\ 75 & 62 & 38 & - & - & - \\ 34 & 61 & 37 & 1 & - & - \\ 84 & 100 & - & - & - & -\end{array}$

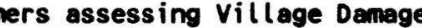

$\begin{array}{llrl}\text { Samangan } & 25 & 125 & 87 \\ \text { Darae Souf } & 13 & 65 & 52 \\ \text { Khulm } & 14 & 70 & 42 \\ \text { Roye Doab } & 16 & 79 & 66\end{array}$

70
80
60
84

$\begin{array}{rrrrr}61 & 28 & 10 & - & 2 \\ 58 & 25 & 17 & - & - \\ 80 & 7 & 9 & 1 & 3 \\ 16 . & 71 & 13 & - & -\end{array}$

77
49
24
66

$\begin{array}{rrrrrr}62 & 81 & 18 & 2 & - & - \\ 75 & 71 & 22 & 8 & - & - \\ 34 & 96 & 3 & 1 & - & - \\ 84 & 25 & 59 & 13 & 3 & -\end{array}$

Roye Doab

65
70
79

$\begin{array}{llllll}70 & 48 & 24 & 24 & 4 & - \\ 80 & 51 & 29 & 20 & - & - \\ 60 & 73 & 10 & 14 & 3 & - \\ 84 & 11 & 71 & 18 & - & -\end{array}$

77
49
24
66

$\begin{array}{llllll}62 & 65 & 30 & 4 & 1 & - \\ 75 & 66 & 25 & 9 & - & - \\ 34 & 89 & 10 & 1 & - & - \\ 84 & 18 & 77 & 5 & - & -\end{array}$


Table 12. Baghlan

Irrigated theat - sumn pest and Locust damage

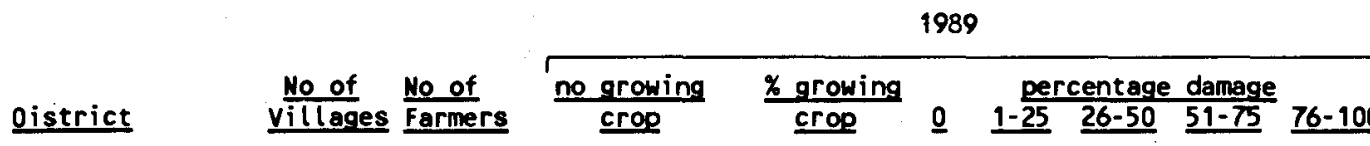

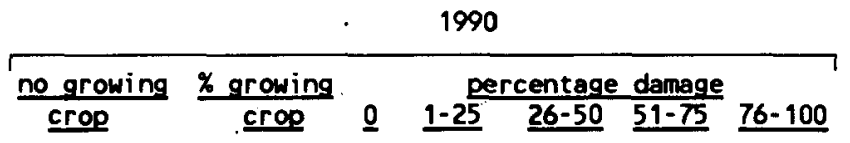

sumpest

Perçentage of Farmers assessing Own Oamage

$\begin{array}{lrrr}\text { Mahrein } & 20 & 100 & 20 \\ \text { Khost Wa fren } & 9 & 44 & 32\end{array}$

Percentage of Farmers assessing Village 0amage

\section{Nahrein}

$\begin{array}{rrr}20 & 100 & 20 \\ 9 & 44 & 32\end{array}$

$20 \quad 100$

Khost Wa fren

9

20

20

\section{Locusts}

Percentage of Farmers assessing Own 0amage

$\begin{array}{lrrr}\text { Mahrein } & 20 & 100 & 20 \\ \text { Khost Wa fren } & 9 & 44 & 32\end{array}$

Percentage of Farmers assessing Village Oamage

Nahrein

Khost we fren

20
9

100
44

20

$\begin{array}{ll}20 & 100 \\ 73 & 100\end{array}$

20
32

20
32

$\begin{array}{ll}20 & 100 \\ 73 & 100\end{array}$

20

$\begin{array}{ll}20 & 100 \\ 73 & 100\end{array}$

$\begin{array}{rrrrrr}20 & 95 & - & 5 & - & - \\ 73 & 100 & - & - & - & -\end{array}$

20

32

$\begin{array}{ll}20 & 100 \\ 73 & 100\end{array}$


Table 13. Baghlan

Rainfed theat - Sunn pest and Locust damage

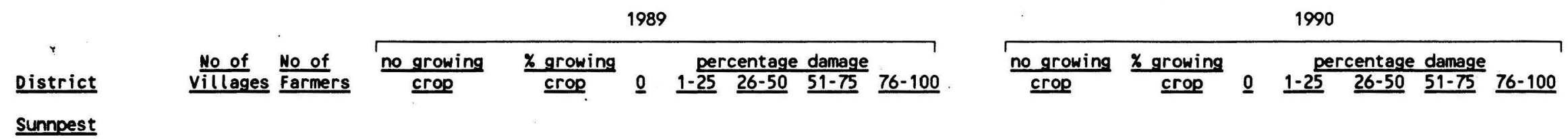

Percentage of Farmers assessing Own Damage

$\begin{array}{lrrr}\text { Nahrein } & 20 & 100 & 48 \\ \text { Khost Wa fren } & 9 & 44 & 7\end{array}$

Percentage of Farmers assessing Village Damage

Mahrein

20100

$\begin{array}{rr}100 & 48 \\ 44 & 7\end{array}$

\section{Locusts}

Percentage of Farmers assessing Own Damage

$\begin{array}{lrrr}\text { Nahrein } & 20 & 100 & 48 \\ \text { Khost Wa fren } & 9 & 44 & 7 \\ & & & \end{array}$

\section{Nahrein}

$\begin{array}{rrr}20 & 100 & 48 \\ 9 & 44 & 7\end{array}$

Khost Wa fren

9

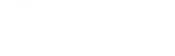


Table 14. Baghlan

Barley - Sunn pest and Locust damage

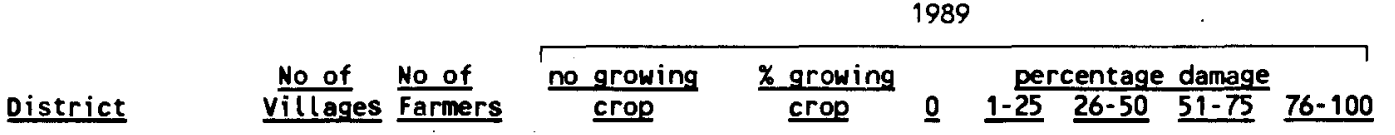

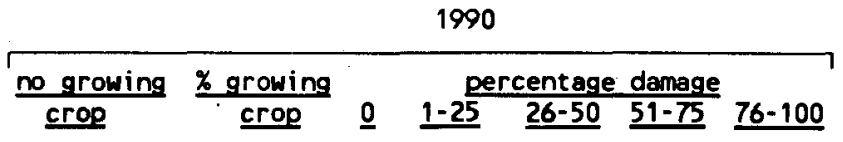

Sunnpest

Percentage of Farmers assessing Own Damage

Nahrein $\quad 20 \quad 100$

Khost Wa fren $\quad 9 \quad 44 \quad 25$

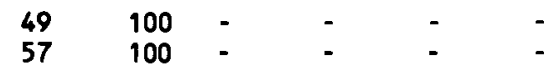

$\begin{array}{lllllll}54 & 54 & 100 & - & - & - & - \\ 23 & 52 & 100 & - & - & - & -\end{array}$

Percentage of Farmers assessing Village Damage

Mahrein

$\begin{array}{rrr}20 & 100 & 49 \\ 9 & 44 & 25\end{array}$

49

$\begin{array}{rrrrrr}49 & 95 & 2 & 3 & - & - \\ 57 & 100 & - & - & - & -\end{array}$

54
23

$\begin{array}{ll}54 & 100 \\ 52 & 100\end{array}$

Locusts

Percentage of Farmers assessing Own Damage

Nahrein

$\begin{array}{rrr}20 & 100 & 49 \\ 9 & 44 & 25\end{array}$

49
57

$\begin{array}{rrrrrr}49 & 92 & 1 & 4 & 3 & - \\ 57 & 80 & 2 & 5 & - & 14\end{array}$

54
23

$\begin{array}{rrrrrr}54 & 93 & - & 2 & 5 & - \\ 52 & 80 & 2 & 2 & 5 & 11\end{array}$

Percentage of Farmers assessing Village Damage

Nahrein

$\begin{array}{rrr}20 & 100 & 49 \\ 9 & 44 & 25\end{array}$

49
25

$\begin{array}{rrrrrr}49 & 82 & 4 & 11 & 3 & - \\ 57 & 68 & 2 & 7 & 7 & 16\end{array}$

54
23

$\begin{array}{rrrrrr}54 & 82 & 4 & 6 & 8 & - \\ 52 & 68 & 2 & 7 & 7 & 16\end{array}$

$44 \quad 25$

$\begin{array}{llllll}57 & 68 & 2 & 7 & 7 & 16\end{array}$




\section{Table 15. Kunduz}

Irrigated theat - Sunn pest and Locust damage

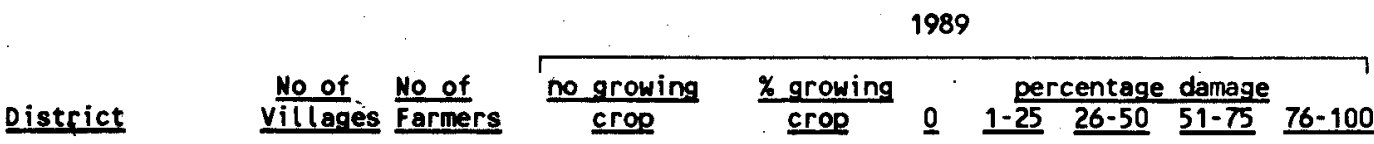

1990
$\frac{\text { no growing }}{\underline{\text { crop }}} \frac{\text { growing }}{\underline{\text { crop }}} \stackrel{\frac{1-25}{\text { percentage damage }}}{\underline{26-50}} \stackrel{51-75}{76-100}$

\section{Sunnpest}

Percentage of Farmers assessing Own Damage

$\begin{array}{lrrr}\text { Kunduz } & 32 & 160 & 132 \\ \text { Al iabad } & 13 & 65 & 58 \\ \text { Hazarat Imem } & 13 & 65 & 47 \\ \text { L jamabed } & 13 & 65 & 31 \\ \text { Archi } & 5 & 25 & 15 \\ \text { Char Dara } & 12 & 60 & 51\end{array}$

Percentage of Farmers assessing Village Damage

Kunduz

Hazarat Imam

L jamabed

Archi

Char Dara

$\begin{array}{rrr}.32 & 160 & 132 \\ 13 & 65 & 58 \\ 13 & 65 & 47 \\ 13 & 65 & 31 \\ 5 & 25 & 15 \\ 12 & 60 & 51\end{array}$

Locusts

Percentage of Farmers assessing Own Damage

$\begin{array}{lrrr}\text { Kunduz } & 32 & 160 & 132 \\ \text { Aliabad } & 13 & 65 & 58 \\ \text { Hazarat Imam } & 13 & 65 & 47 \\ \text { L jamabad } & 13 & 65 & 31 \\ \text { Archi } & 5 & 25 & 15 \\ \text { Char Dara } & 12 & 60 & 51\end{array}$

Char Dara

60

$\begin{array}{rrr}83 & 100 & - \\ 89 & 100 & - \\ 72 & 91 & 9 \\ 48 & 100 & - \\ 60 & 100 & - \\ 85 & 95 & 2\end{array}$

128
58
50
31
16
55

$\begin{array}{rrrrrr}80 & 100 & - & - & - & - \\ 89 & 100 & - & - & - & - \\ 77 & 91 & 9 & - & - & - \\ 48 & 100 & - & - & - & - \\ 64 & 100 & - & - & - & - \\ 92 & 100 & - & - & - & -\end{array}$

Percentage of Farmers assessing Village Damage

\section{Kunduz}

Al i abad

Hazarat Imam

L jamabed

Char Dara

$\begin{array}{rrr}32 & 160 & 132 \\ 13 & 65 & 58 \\ 13 & 65 & 47 \\ 13 & 65 & 31 \\ 5 & 25 & 15 \\ 12 & 60 & 51\end{array}$

$\begin{array}{rrr}83 & 100 & - \\ 89 & 100 & - \\ 72 & 85 & 15 \\ 48 & 100 & - \\ 60 & 100 & - \\ 85 & 93 & 7\end{array}$

$\begin{array}{rrr}83 & 100 & - \\ 89 & 100 & - \\ 72 & 77 & 23 \\ 48 & 100 & - \\ 60 & 100 & - \\ 85 & 80 & 17\end{array}$

$\begin{array}{rrr}83 & 100 & - \\ 89 & 100 & - \\ 72 & 71 & 29 \\ 48 & 100 & - \\ 60 & 100 & - \\ 85 & 68 & 32\end{array}$

$\begin{array}{rrrrrr}80 & 100 & - & - & - & - \\ 89 & 100 & - & - & - & - \\ 77 & 85 & 15 & - & - & - \\ 48 & 100 & - & - & - & - \\ 64 & 100 & - & - & - & - \\ 92 & 100 & - & - & - & -\end{array}$

$\begin{array}{rrrrrr}80 & 100 & - & - & - & - \\ 89 & 100 & - & - & - & - \\ 77 & 77 & 23 & - & - & - \\ 48 & 100 & - & - & - & - \\ 64 & 100 & - & - & - & - \\ 92 & 95 & 5 & - & - & -\end{array}$




\section{Iable 16. Kunduz}

Rainfed theat - Sunn pest and Locust damage

1989

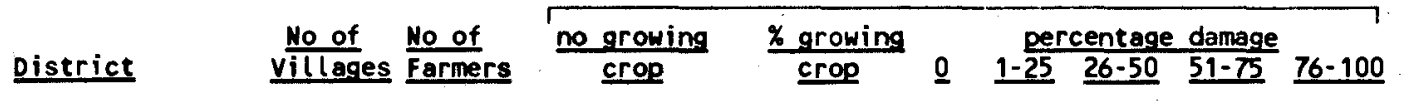

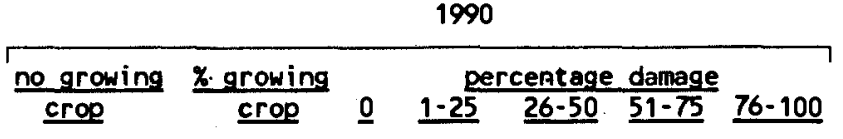

Sumpest

Percentage of Farmers assessing Own Damage

$\begin{array}{lrrr}\text { Kunduz } & 32 & 160 & 3 \\ \text { Aliabad } & 13 & 65 & 35 \\ \text { Hazarat Imam } & 13 & 65 & - \\ \text { Ljamabad } & 13 & 65 & 20 \\ \text { Archi } & 5 & 25 & 4 \\ \text { Char Dara } & 12 & 60 & 8 \\ & & \end{array}$

assessing Village Damage

$\begin{array}{lrrr}\text { Kunduz } & 32 & 160 & 3 \\ \text { Al iabad } & 13 & 65 & 35 \\ \text { Hazarat Imam } & 13 & 65 & - \\ \text { L jamabed } & 13 & 65 & 20 \\ \text { Arčhi } & 5 & 25 & 4 \\ \text { Char Dara } & 12 & 60 & 8\end{array}$

Char Dara

Locusts

Percentage of Farmers assessing Own Damage

$\begin{array}{lrrr}\text { Kunduz } & 32 & 160 & 3 \\ \text { Al i iabad } & 13 & 65 & 35 \\ \text { Hazarat I man } & 13 & 65 & - \\ \text { L jamabad } & 13 & 65 & 20 \\ \text { Archi } & 5 & 25 & 4 \\ \text { Char Dara } & 12 & 60 & 8\end{array}$

Percentage of Farmers assessing Village Damage

$\begin{array}{lrrrrrr}\text { Kunduz } & 32 & 160 & 3 & 2 & 100 & - \\ \text { Al iabad } & 13 & 65 & 35 & 54 & 95 & 5 \\ \text { Hazarat Imam } & 13 & 65 & - & - & - & - \\ \text { L jamabad } & 13 & 65 & 20 & 31 & 100 & - \\ \text { Archi } & 5 & 25 & 4 & 16 & 100 & - \\ \text { Char Dara } & 12 & 60 & 8 & 13 & 90 & 10\end{array}$

Char Dara

60

\begin{tabular}{|c|c|c|c|c|}
\hline 2 & 100 & - & - & - \\
\hline 4 & 100 & - & - & - \\
\hline & 10 & 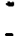 & 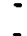 & 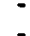 \\
\hline 16 & 100 & - & - & - \\
\hline 13 & 100 & - & . & - \\
\hline
\end{tabular}

2
11
18
4
11

$\begin{array}{rrrrrr}1 & 100 & - & - & - & - \\ 17 & 100 & - & - & - & - \\ 28 & 100 & - & - & - & - \\ 16 & 100 & - & - & - & - \\ 18 & 100 & - & - & - & -\end{array}$

90 


\section{Iable 17. Kunduz}

Barley - Sumn pest and Locust damage

1989

1990

District

villages $\frac{\text { No of }}{\text { Farmers }}$

\begin{tabular}{r}
\hline no grow \\
crop \\
\\
\\
43 \\
4 \\
1 \\
28
\end{tabular}

Sunnpest

Percentage of Farmers assessing Own Damage

$\begin{array}{lrrr}\text { Kunduz } & 32 & 160 & 43 \\ \text { Ali iabad } & 13 & 65 & 41 \\ \text { Hazarat Imam } & 13 & 65 & - \\ \text { L jamabad } & 13 & 65 & 1 \\ \text { Archi } & 5 & 25 & - \\ \text { Char Dara } & 12 & 60 & 28\end{array}$

Percentage of Farmers assessing vill age Damage

Kunduz
Al iabad
Hazarat Imam
L jamabad
Archi

Char Dara

$\begin{array}{rrr}32 & 160 & 43 \\ 13 & 65 & 41 \\ 13 & 65 & - \\ 13 & 65 & 1 \\ 5 & 25 & - \\ 12 & 60 & 28\end{array}$

Locusts

Percentage of Farmers assessing Own Damage

$\begin{array}{lrrr}\text { Kunduz } & 32 & 160 & 43 \\ \text { Al iabad } & 13 & 65 & 41 \\ \text { Hazarat Imam } & 13 & 65 & - \\ \text { L jamabad } & 13 & 65 & 1 \\ \text { Archi } & 5 & 25 & - \\ \text { Char Dara } & 12 & 60 & 28\end{array}$

Char Dara

28

Percentage of Farmers assessing Village Damage

Kunduz

Al i abad

Hazarat Imam

L jamabad

Arch i

Char Dara

$\begin{array}{rrr}32 & 160 & 43 \\ 13 & 65 & 41 \\ 13 & 65 & - \\ 13 & 65 & 1 \\ 5 & 25 & - \\ 12 & 60 & 28\end{array}$

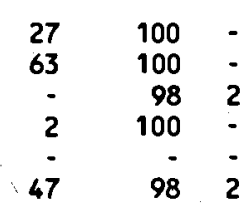

$\begin{array}{rrr}27 & 100 & - \\ 63 & 100 & - \\ - & 92 & 8 \\ 2 & 94 & 6 \\ - & - & - \\ 47 & 95 & 5\end{array}$

61
41
4
17
1
27

$\begin{array}{rrrrrr}38 & 100 & - & - & - & - \\ 63 & 100 & - & - & - & - \\ 6 & 95 & 5 & - & - & - \\ 26 & 100 & - & - & - & - \\ 4 & 100 & - & - & - & - \\ 45 & 100 & - & - & - & -\end{array}$

$\begin{array}{rrrrrr}38 & 100 & - & - & - & - \\ 63 & 100 & - & - & - & - \\ 6 & 98 & 2 & - & - & - \\ 26 & 97 & 3 & - & - & - \\ 4 & 100 & - & - & - & - \\ 45 & 100 & - & - & - & -\end{array}$

$\begin{array}{rrrrrr}38 & 100 & - & - & - & - \\ 63 & 100 & - & - & - & - \\ 6 & 92 & 8 & - & - & - \\ 26 & 94 & 6 & - & - & - \\ 14 & 100 & - & - & - & - \\ 45 & 100 & - & - & - & -\end{array}$

$\begin{array}{rrrrrr}27 & 100 & - & - & - & - \\ 63 & 100 & - & - & - & - \\ - & 85 & 15 & - & - & - \\ 2 & 100 & - & - & - & - \\ 47 & 85 & 13 & 2 & - & -\end{array}$

61
41
4
17
1
27

$\begin{array}{rrr}38 & 100 & \\ 63 & 100 & \\ 6 & 85 & 15 \\ 26 & 100 & \\ 4 & 100 & \\ 45 & 98 & 2\end{array}$


Table 18. Takhar

Irrigated theat - Sunn pest and Locust damage

1989

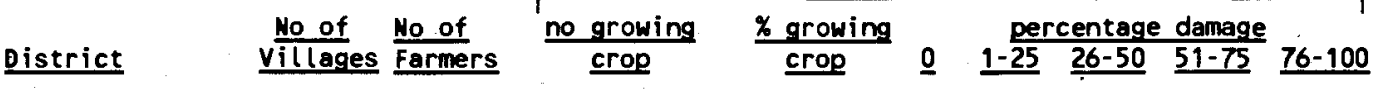
Sunnpest

Pencentage of Farmers assessing Own Damage

$\begin{array}{lrrr}\text { Taloqan } & 17 & 85 & 58 \\ \text { Rustaq } & 1 & 5 & \\ \text { Khwajaghar } & 12 & 59 & 33 \\ \text { Eshkamesh } & 18 & 85 & 34 \\ \text { Bangi } & 1 & 5 & \end{array}$

Percentage of Farmers assessing Village Damage

\section{Taloqan}

Rustaq

Khwa jaghar

Eshkames

Bangi

$\begin{array}{rrr}17 & 85 & 58 \\ 1 & 5 & - \\ 12 & 59 & 33 \\ 18 & 85 & 34 \\ 1 & 5 & 4\end{array}$

Locusts

Percentage of Farmers assessing Own Damage

Talogan

Rustaq

Khwajaghar

Eshkamesh

Bangi

$\begin{array}{rrr}17 & 85 & 58 \\ 1 & 5 & - \\ 12 & 59 & 33 \\ 18 & 85 & 34 \\ 1 & 5 & 4\end{array}$

68
56
40

$\begin{array}{rr}68 & 100 \\ - & - \\ 56 & 100 \\ 40 & 100\end{array}$

Percentage of Farmers assessing Village Damage

Taloqan

Rusteq

Khwa jaghar

Eshkamesh

Bangi

$\begin{array}{rr}17 & 85 \\ 1 & \\ 12 & 59 \\ 18 & 8 \\ 1 & \end{array}$

$\begin{array}{rrr}68 & 100 & - \\ - & - & - \\ 56 & 100 & - \\ 40 & 100 & - \\ 80 & 100 & -\end{array}$

68
56
40
80

100
-
100
100

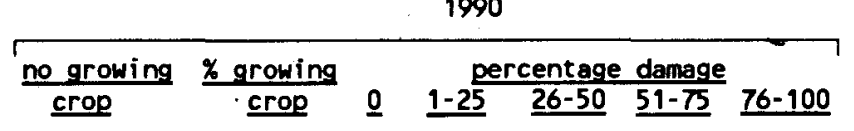


Table 19. Takhar

Rainfed Wheat - Sunn pest and Locust damage

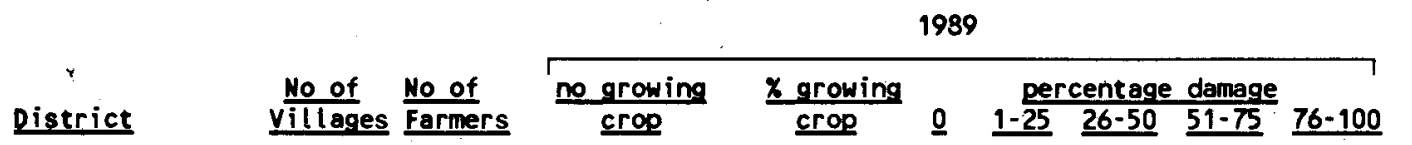

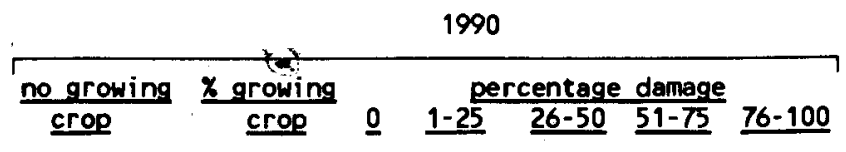

sumnest.

Percentage of Farmers assessing Own Damage

$\begin{array}{lrrr}\text { Taloqar } & 17 & 85 & 12 \\ \text { Rustaq } & 1 & 5 & 4 \\ \text { Khwa jaghar } & 12 & 59 & 19 \\ \text { Eshkamesh } & 18 & 85 & 45 \\ \text { Bangi } & 1 & 5 & 2\end{array}$

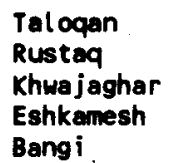

$\begin{array}{rrr}17 & 85 & 12 \\ 1 & 5 & 4 \\ 12 & 59 & 19 \\ 18 & 85 & 45 \\ 1 & 5 & 2\end{array}$

$\begin{array}{lll}14 & 100 & \\ 80 & 100 & \\ 32 & 100 & - \\ 53 & 100 & = \\ 40 & 100\end{array}$

Locusts

Percentage of Farmers assessing Own Damage

$\begin{array}{lrrr}\text { Taloqan } & 17 & 85 & 12 \\ \text { Rustaq } & 1 & 5 & 4 \\ \text { Khwa jaghar } & 12 & 59 & 19 \\ \text { Eshkameshi } & 18 & 85 & 45 \\ \text { Bangi } & 1 & 5 & 2\end{array}$

Percentage of Farmers assessing Village Damage

$\begin{array}{lrrr}\text { Taloqan } & 17 & 85 & 12 \\ \text { Rustaq } & 1 & 5 & 4 \\ \text { Khwajaghar } & 12 & 59 & 19 \\ \text { Eshkamesh } & 18 & 85 & 45 \\ \text { Bangi } & 1 & 5 & 2\end{array}$

$\begin{array}{rrr}14 & 100 & - \\ 80 & 100 & - \\ 32 & 100 & - \\ 53 & 89 & 5 \\ 40 & 100 & -\end{array}$

13
1
31
43

$\begin{array}{cccccc}15 & 100 & - & - & - & - \\ 20 & 100 & - & - & - & - \\ 53 & 100 & - & - & - & - \\ 51 & 100 & - & - & - & - \\ - & - & - & - & - & -\end{array}$

$\begin{array}{rrrrrr}14 & 100 & - & - & - & - \\ 80 & 100 & - & - & - & - \\ 32 & 100 & - & - & - & - \\ 53 & 88 & - & 6 & - & 6 \\ 40 & 100 & - & - & - & -\end{array}$

13
1
31
43

$\begin{array}{rrrrrr}15 & 100 & - & - & - & - \\ 20 & 100 & - & - & - & - \\ 53 & 100 & - & - & - & - \\ 51 & 100 & - & - & - & - \\ - & - & - & - & - & -\end{array}$


Table 20. Takhar

Barley - Sunn pest and Locust damage

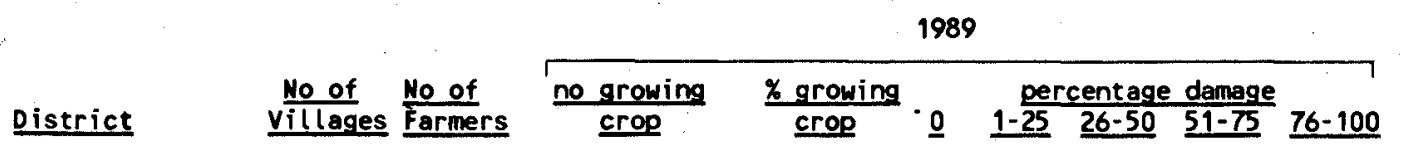

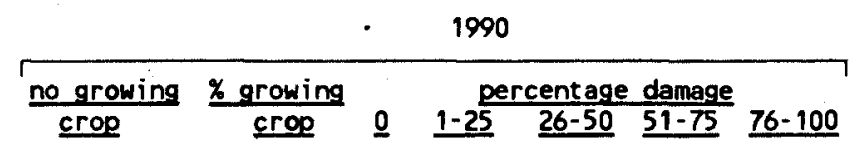

Sunnpest

Percentage of Farmers assessing Own Damage

$\begin{array}{lrrr} & & & \\ \text { Taloqan } & 17 & 85 & 13 \\ \text { Rustaq } & 1 & 5 & 4 \\ \text { Khwajaghar } & 12 & 59 & 37 \\ \text { Eshkamesh } & 18 & 85 & 56 \\ \text { Bangi } & 1 & 5 & -\end{array}$

$\begin{array}{cccccc}15 & 100 & - & - & - & - \\ 80 & 100 & - & - & - & - \\ 63 & 100 & - & - & - & - \\ 66 & 100 & - & - & - & - \\ - & - & - & - & - & -\end{array}$

14
3
34
50

$\begin{array}{llllll}17 & 100 & - & - & - & - \\ 60 & 100 & - & - & - & - \\ 58 & 100 & - & - & - & - \\ 59 & 100 & - & - & - & - \\ - & - & - & - & - & -\end{array}$

Percentage of Farmers assessing Village Damage

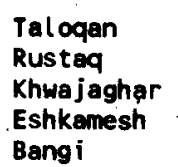

$\begin{array}{rrr}17 & 85 & 13 \\ 1 & 5 & 4 \\ 12 & 59 & 37 \\ 18 & 85 & 56 \\ 1 & 5 & -\end{array}$

$\begin{array}{llllll}15 & 100 & - & - & - & - \\ 80 & 100 & - & - & - & - \\ 63 & 100 & - & - & - & - \\ 66 & 100 & - & - & - & - \\ - & - & - & - & - & -\end{array}$

14
3
34
50

$\begin{array}{rrrrrr}17 & 100 & - & - & - & - \\ 60 & 100 & - & - & - & - \\ 58 & 100 & - & - & - & - \\ 59 & 100 & - & - & - & - \\ - & - & - & - & - & -\end{array}$

Locusts

Percentage of Farmers assessing Oun Damage

$\begin{array}{lrrr}\text { Taloqan } & 17 & 85 & 13 \\ \text { Rustaq } & 1 & 5 & 4 \\ \text { Khwajaghar } & 12 & 59 & 37 \\ \text { Eshkamesh } & 18 & 85 & 56 \\ \text { Bangi } & 1 & 5 & \end{array}$

Percentage of Farmers assessing Village Damage

Talogan Rusteq Khwa jaghar Eshkamesh Bangi

$\begin{array}{rrr}17 & 85 & 13 \\ 1 & 5 & 4 \\ 12 & 59 & 37 \\ 18 & 85 & 56 \\ 1 & 5 & -\end{array}$

$\begin{array}{cccccc}15 & 100 & - & - & - & - \\ 80 & 100 & - & - & - & - \\ 63 & 100 & - & - & - & - \\ 66 & 100 & - & - & - & - \\ - & - & - & - & - & -\end{array}$

14
3
34
50
-

$\begin{array}{lccccc}17 & 100 & - & - & - & - \\ 60 & 100 & - & - & - & - \\ 58 & 100 & - & - & - & - \\ 59 & 100 & - & - & - & - \\ - & - & - & - & - & -\end{array}$

$\begin{array}{ccc}15 & 100 \\ 80 & 100 \\ 63 & 100 \\ 66 & 100= \\ - & -\end{array}$

$\begin{array}{rrrrrr}17 & 100 & - & - & - & - \\ 60 & 100 & - & - & - & - \\ 58 & 100 & - & - & - & - \\ 59 & 100 & - & - & - & - \\ - & - & - & - & - & -\end{array}$


Table 21. Badakhshan

Irrigated Wheat - Sunn pest and Locust damage

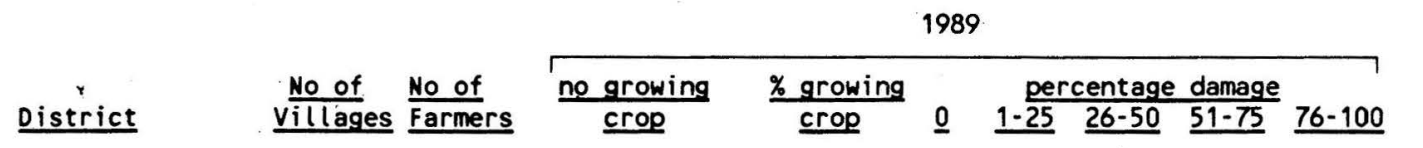

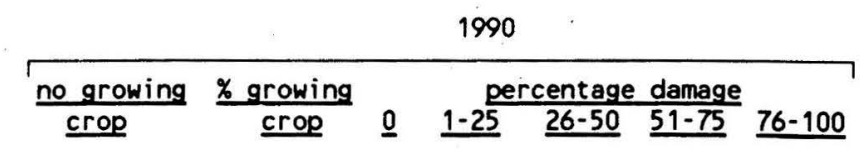
Sunnpest

Percentage of Farmers assessing Own Damage

Faizabad

Ragh

Sahre Bozurg

Jurm

Baharak

Eshkashem

Kesham

$\begin{array}{rrr}19 & 95 & 22 \\ 1 & 1 & - \\ 8 & 39 & - \\ 10 & 55 & 50 \\ 8 & 35 & 25 \\ 1 & 5 & - \\ 24 & 125 & 83\end{array}$

$\begin{array}{rrr}23 & 100 & - \\ - & - & - \\ - & - & - \\ 91 & 100 & - \\ 71 & 86 & - \\ - & - & - \\ 66 & 100 & -\end{array}$

Percentage of Farmers assessing Village Damage

Faizabad

Ragh

Sahre Bozurg

Jurm

Baharak

Eshkashem

Kesham

$\begin{array}{rrr}19 & 95 & 22 \\ 1 & 1 & - \\ 8 & 39 & - \\ 10 & 55 & 50 \\ 8 & 35 & 25 \\ 1 & 5 & - \\ 24 & 125 & 83\end{array}$

Locusts

Percentage of Farmers assessing Own Damage

\section{Faizabed}

Ragh

Sahre Bozurg

Jurm

Baharak

Eshkashem

Kesham

19
1
8
10
8
1
24

95
1
39
55
35
5
125

22
-
50
25
-
83

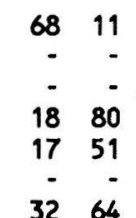

Percentage of Farmers assessing Village Damage

Faizabed

Ragh

Sahre Bozurg

Jurm

Baharak

Eshkashem

19
1
8
10
8
1
24

95
1
39
55
35
5
125

22
-
50
25
-
83
23
-
91
71
-
66

$\begin{array}{rr}23 & 100 \\ - & - \\ - & - \\ 91 & 100 \\ 71 & 86 \\ - & - \\ 66 & 100\end{array}$

23
-
91
71
-
66

Kesham

83

$\begin{array}{rrrrr}68 & 11 & 11 & 6 & 4 \\ - & - & - & - & - \\ - & - & - & - & - \\ 18 & 80 & 2 & - & - \\ 14 & 57 & 29 & - & - \\ - & - & - & - & - \\ 32 & 12 & 56 & - & -\end{array}$

20
-
52
24
82

$\begin{array}{rr}21 & 100 \\ - & - \\ 95 & 100 \\ 69 & 86 \\ - & - \\ 66 & 100\end{array}$

$\begin{array}{rrrrrr}21 & 100 & - & - & - & - \\ - & - & - & - & - & - \\ - & - & - & - & - & - \\ 95 & 100 & - & - & - & - \\ 69 & 86 & - & 14 & - & - \\ - & - & - & - & - & - \\ 66 & 100 & - & - & - & -\end{array}$

11
-
2
31
-

6
-
-
-

$\begin{array}{ll}6 & 4 \\ - & - \\ - & - \\ - & - \\ - & -\end{array}$

20
-
52
24
-

82

$\begin{array}{rrrrrr}21 & 68 & 6 & 8 & 7 & 9 \\ - & - & - & - & - & - \\ 95 & 18 & 24 & 58 & - & - \\ 69 & 17 & 9 & 74 & - & - \\ - & - & - & - & - & - \\ 66 & 32 & 68 & - & - & -\end{array}$


Iable 22. Badakhshan

Rainfed theat - Sunn pest and Locust damage

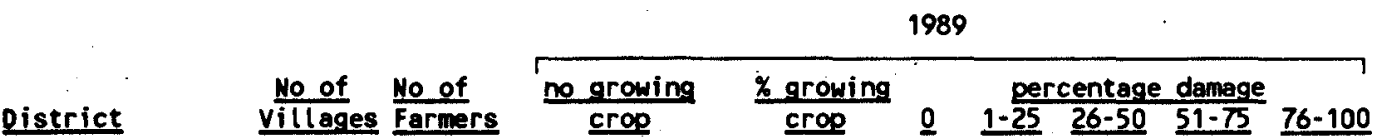

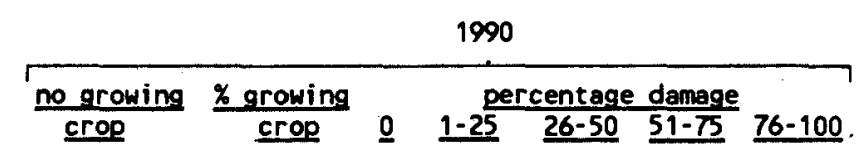

sunnpest

Percentage of Farmers assessing Own Damage

Faizabed

Ragh

Sahre Bozurg

Jurm

Baharak

Eshkashem

Keshan

$\begin{array}{rr}19 & 95 \\ 1 & 1 \\ 8 & 39 \\ 10 & 55 \\ 8 & 35 \\ 1 & 5\end{array}$

$$
\begin{array}{r}
67 \\
1 \\
31 \\
17 \\
- \\
4 \\
64
\end{array}
$$

$\begin{array}{rr}71 & 100 \\ 100 & 100 \\ 80 & 100 \\ 31 & 100 \\ 8 & - \\ 80 & 100 \\ 51 & 99\end{array}$

Percentage of Farmers assessing Village Damage

Faizabad

Ragh

Sahre Bozurg

Jurm

Baharak

Eshkashem

Kesham

$\begin{array}{rrr}19 & 95 & 67 \\ 1 & 1 & 1 \\ 8 & 39 & 31 \\ 10 & 55 & 17 \\ 8 & 35 & - \\ 1 & 5 & 4 \\ 24 & 125 & 64\end{array}$

$\begin{array}{rrr}71 & 100 & = \\ 100 & 100 & - \\ 80 & 100 & = \\ 31 & 100 & - \\ - & - & - \\ 80 & 100 & - \\ -51 & 99 & -\end{array}$

\section{Locusts}

Percentoge of Farmers assessing Oun Damage

$\begin{array}{lrr}\text { Faizabad } & 19 & 95 \\ \text { Ragh } & 1 & 1 \\ \text { Sahre Bozurg } & 8 & 39 \\ \text { Jurm } & 10 & 55 \\ \text { Baharak } & 8 & 35 \\ \text { Eshkashem } & 1 & 5 \\ \text { Kesham } & 24 & 125\end{array}$

$\begin{array}{rrrrrrr}67 & 71 & - & 32 & 25 & 33 & 11 \\ 1 & 100 & -100 & - & - & - \\ 31 & 80 & -100 & - & - & - \\ 17 & 31 & 47 & 36 & 16 & - & - \\ - & - & - & - & - & - & - \\ 4 & 80 & 20 & 80 & - & - & - \\ 64 & 51 & 1 & 98 & 1 & - & -\end{array}$

Percentage of Farmers assessing Village Damage

$\begin{array}{lrrrrrrrrr}\text { Faizabed } & 19 & 95 & 67 & 71 & - & 31 & 26 & 33 & 11 \\ \text { Ragh } & 1 & 1 & 1 & 100 & -100 & - & - & - \\ \text { Sahre Bozurg } & 8 & 39 & 31 & 80 & 3 & 97 & - & - & - \\ \text { Jurm } & 10 & 55 & 17 & 31 & 47 & 29 & 24 & - & - \\ \text { Baharak } & 8 & 35 & - & - & - & - & - & - & - \\ \text { Eshkashem } & 1 & 5 & 4 & 80 & 20 & 80 & - & - & - \\ \text { Kesham } & 24 & 125 & 64 & 51 & 1 & 32 & 66 & - & -\end{array}$

Kesham

$\begin{array}{rrrrrrr}70 & 74 & 100 & - & - & - & - \\ 1 & 100 & 100 & - & - & - & - \\ 31 & 80 & 100 & - & - & - & - \\ 13 & 24 & 100 & - & - & - & - \\ - & - & - & - & - & - & - \\ 4 & 80 & 100 & - & - & - & - \\ 71 & 57 & 99 & 1 & - & - & -\end{array}$

$\begin{array}{rrrrrrr}70 & 74 & 100 & - & - & - & - \\ 1 & 100 & 100 & - & - & - & - \\ 31 & 80 & 100 & - & - & - & - \\ 13 & 24 & 100 & - & - & - & - \\ - & - & - & - & - & - & - \\ 4 & 80 & 100 & - & - & - & - \\ 71 & 57 & 99 & - & 1 & - & -\end{array}$


Table 23. Badakhshan

Barley - Sunn pest and Locust damage

District $\frac{\text { No of }}{\text { villages }} \frac{\text { No of }}{\text { Farmers }} \frac{\text { no growing }}{\text { crop }} \frac{\text { zagrowing }}{\text { crop }} \underline{\frac{0}{1-25} \frac{26-50 \quad 51-75}{26-100}}$

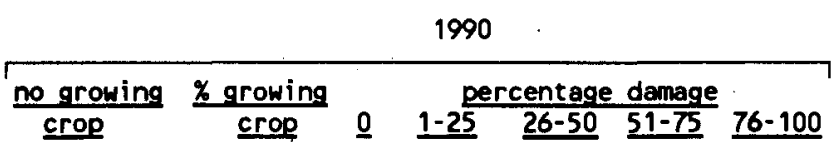

Sunnpest

Percentage of Farmers assessing Own Damage

$\begin{array}{lrrr}\text { Faizabad } & 19 & 95 & 73 \\ \text { Ragh } & 1 & 1 & 1 \\ \text { Sahre Bozurg } & 8 & 39 & 30 \\ \text { Jurm } & 10 & 55 & 49 \\ \text { Baharak } & 8 & 35 & 27 \\ \text { Eshkashem } & 1 & 5 & 3 \\ \text { Kesham } & 24 & 125 & 112\end{array}$

Percentage of Farmers assessing Village Damage

$\begin{array}{lrrr}\text { Faizabad } & 19 & 95 & 75 \\ \text { Ragh } & 1 & 1 & \\ \text { Sahre Bozurg } & 8 & 39 & 30 \\ \text { Jurm } & 10 & 55 & 49 \\ \text { Baharak } & 8 & 35 & 27 \\ \text { Eshkashem } & 1 & 5 & \\ \text { Kesham } & 24 & 125 & 112\end{array}$

Eshkashem

24

125

73
1
30
49
27
3
112

77
100
77
89
77
60
90

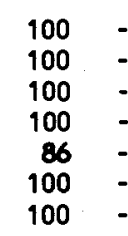

66
1
29
46
25
3
111

$\begin{array}{rr}70 & 100 \\ 100 & 100 \\ 74 & 100 \\ 84 & 100 \\ 71 & 86 \\ 60 & 100 \\ 89 & 100\end{array}$

Locusts

Percentage of Farmers assessing Own Damage

$\begin{array}{lrrr}\text { Faizabad } & 19 & 95 & 73 \\ \text { Ragh } & 1 & 1 & 1 \\ \text { Sahre Bozurg } & 8 & 39 & 30 \\ \text { Jurm } & 10 & 55 & 49 \\ \text { Baharak } & 8 & 35 & 27 \\ \text { Eshkashem } & 1 & 5 & 3 \\ \text { Kesham } & 24 & 125 & 112\end{array}$

$\begin{array}{rrr}77 & 100 & \\ 100 & 100 & \\ 77 & 100 & - \\ 89 & 100 & - \\ 77 & 86 & - \\ 60 & 100 & \\ 90 & 100 & \end{array}$

66
1
29
46
25
3
111

$\begin{array}{rr}70 & 100 \\ 100 & 100 \\ 74 & 100 \\ 84 & 100 \\ 71 & 86 \\ 60 & 100 \\ 89 & 100\end{array}$

Percentage of Farmers assessing Village Damage

Faizabad

Ragh

Sahre Bozurg

Jurm

Baharak

Eshkashem

Kesham

$\begin{array}{rr}95 & 73 \\ 1 & 1 \\ 39 & 30 \\ 55 & 49 \\ 35 & 27 \\ 5 & 3 \\ 125 & 112\end{array}$

$\begin{array}{rrrrrr}77 & - & 32 & 49 & 13 & 6 \\ 100 & -100 & - & - & - \\ 77 & - & 100 & - & - & - \\ 89 & 100 & - & - & - & - \\ 77 & 14 & 83 & - & - & - \\ 60 & - & 100 & - & - & - \\ 90 & 77 & 23 & - & - & -\end{array}$

66
1
29
46
25
3
111

$\begin{array}{rrrrrr}70 & - & 32 & 32 & 29 & 7 \\ 100 & - & 100 & - & - & - \\ 74 & - & 100 & - & - & - \\ 84 & 100 & - & - & - & - \\ 71 & 14 & 83 & 3 & - & - \\ 60 & - & 100 & - & - & - \\ 89 & 77 & 23 & - & - & -\end{array}$

$\begin{array}{rrrrrr}77 & -32 & 49 & 13 & 6 \\ 100 & -100 & - & - & - \\ 77 & - & 100 & - & - & - \\ 89 & 100 & - & - & - & - \\ 77 & 14 & 86 & - & - & - \\ 60 & - & 100 & - & - & - \\ 90 & 77 & 23 & - & - & -\end{array}$

66
1
29
46
25
3
111

$\begin{array}{rrrrrr}70 & - & 32 & 32 & 29 & 7 \\ 100 & - & 100 & - & - & - \\ 74 & - & 100 & - & - & - \\ 84 & 100 & - & - & - & - \\ 71 & 14 & 83 & 3 & - & - \\ 60 & - & 100 & - & - & - \\ 89 & 77 & 23 & - & - & -\end{array}$


Table 24. Herat

Irrigated theat - Sunn pest and Locust damage

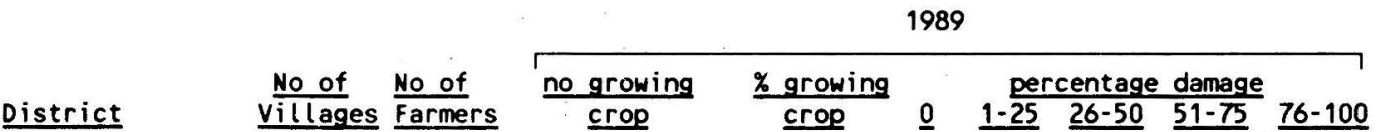

\begin{tabular}{lll} 
& 1990 \\
\hline$\frac{\text { no growing }}{\underline{\text { crop }}} \frac{\text { growing }}{\underline{\text { crop }}} \underline{0} \quad \underline{1-25} \quad \underline{\text { percentage damage }}$ & $\underline{26-50} \quad \underline{51-75} \quad \underline{76-100}$
\end{tabular}

Sunnpest

Percentage of Farmers assessing Own Damage

$\begin{array}{lrll}\text { Enjeel } & 8 & 40 & 37 \\ \text { Gozarah } & 11 & 55 & 46 \\ \text { Pashtoon Zarg } & 4 & 20 & 20 \\ \text { Obey } & 6 & 30 & 29 \\ \text { Zendajan } & 5 & 25 & 22 \\ \text { Adreskan } & 6 & 30 & 26\end{array}$

Percentage of Farmers assessing Village Damage

$\begin{array}{lrrl}\text { Enjeel } & 8 & 40 & 37 \\ \text { Gozarah } & 11 & 55 & 46 \\ \text { Pashtoon Zarg } & 4 & 20 & 20 \\ \text { Obey } & 6 & 30 & 29 \\ \text { Zendajan } & 5 & 25 & 22 \\ \text { Adreskan } & 6 & 30 & 26\end{array}$

Zendajan
Adreskan

Locusts

Percentage of Farmers assessing Own Damage

$\begin{array}{lrrl}\text { Enjeel } & 8 & 40 & 37 \\ \text { Gozarah } & 11 & 55 & 46 \\ \text { Pashtoon Zarg } & 4 & 20 & 20 \\ \text { Obey } & 6 & 30 & 29 \\ \text { Zendajan } & 5 & 25 & 22 \\ \text { Adreskan } & 6 & 30 & 26\end{array}$

Percentage of Farmers assessing Village Damage

Enjeel

Gazhtoon zarg

Obey

Zendajan

Adreskan

$\begin{array}{rr}8 & 40 \\ 11 & 55 \\ 4 & 20 \\ 6 & 30 \\ 5 & 25 \\ 6 & 30\end{array}$

$\begin{array}{rrrrrr}93 & 100 & - & - & - & - \\ 84 & 93 & 7 & - & - & - \\ 100 & 100 & - & - & - & - \\ 97 & 100 & - & - & - & - \\ 88 & 100 & - & - & - & - \\ 87 & 100 & - & - & - & -\end{array}$

39

48

30

19
28

$\begin{array}{rrrrrr}98 & 100 & - & - & - & - \\ 87 & 91 & 7 & 2 & - & - \\ 90 & 100 & - & - & - & - \\ 100 & 100 & - & - & - & - \\ 76 & 100 & - & - & - & - \\ 93 & 100 & - & - & - & -\end{array}$

$\begin{array}{rrrrrr}93 & 100 & - & - & - & - \\ 84 & 91 & 2 & - & 7 & - \\ 100 & 100 & - & - & - & - \\ 97 & 100 & - & - & - & - \\ 88 & 100 & - & - & - & - \\ 87 & 100 & - & - & - & -\end{array}$

39
48
18
30
19
28

98
87
90
100
76
93

$\begin{array}{rrrrr}100 & - & - & - & - \\ 91 & 4 & 5 & - & - \\ 100 & - & - & - & - \\ 100 & - & - & - & - \\ 100 & - & - & - & - \\ 100 & - & - & - & -\end{array}$

39
48
18
30
19
28

$\begin{array}{rrrrrr}98 & 100 & - & - & - & - \\ 87 & 98 & 2 & - & - & - \\ 90 & 100 & - & - & - & - \\ 100 & 100 & - & - & - & - \\ 76 & 100 & - & - & - & - \\ 93 & 100 & - & - & - & -\end{array}$

$\begin{array}{rrrr}37 & 93 & 100 & - \\ 46 & 84 & 93 & 7 \\ 20 & 100 & 100 & - \\ 29 & 97 & 100 & - \\ 22 & 88 & 100 & - \\ 26 & 87 & 100 & -\end{array}$




\section{Table 25. Herat}

Rainfed Wheat - Sunn pest and Locust damage

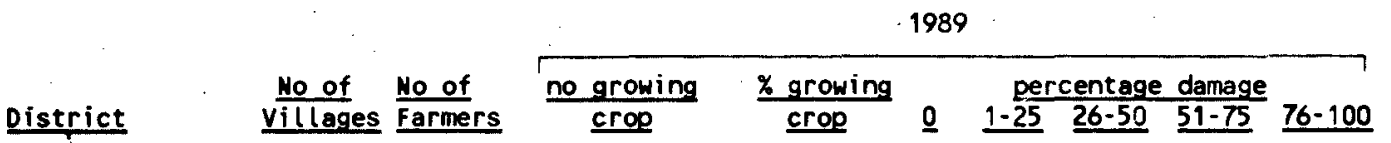

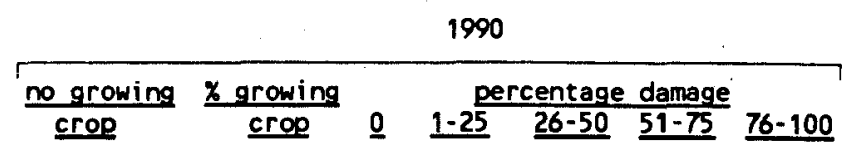

\section{Sunnpest}

Percentage of Farmers assessing Own Damage

Enjeel

Gozarah

Pashtoon Zarg

Obey

Obey jar

Zendajan
Adreskan

$\begin{array}{rr}8 & 40 \\ 11 & 55 \\ 4 & 20 \\ 6 & 30 \\ 5 & 25 \\ 6 & 30\end{array}$

Percentage of Farmers assessing Village Damage

Enjeel

Gozarah

Pashtoon Zarg

Obey

Zendajan

Adreskan

$\begin{array}{rrr}8 & 40 & - \\ 11 & 55 & 3 \\ 4 & 20 & 6 \\ 6 & 30 & - \\ 5 & 25 & - \\ 6 & 30 & -\end{array}$

\section{Locusts}

Percentage' of Farmers assessing Own Damage

Enjeel

Gozarah

Pashtoon Zarg

Obey

Zenda jan

Zendajan
Adreskan

$\begin{array}{rrr}8 & 40 & - \\ 11 & 55 & 3 \\ 4 & 20 & 6 \\ 6 & 30 & - \\ 5 & 25 & - \\ 6 & 30 & -\end{array}$

Percentage of Farmers assessing Village Damage

Enjeel

Gozarah

Pashtoon Zarg

Obey

Zendajan

Adreskan

$\begin{array}{rr}8 & 40 \\ 11 & 55 \\ 4 & 20 \\ 6 & 30 \\ 5 & 25 \\ 6 & 30\end{array}$

$\begin{array}{ll}40 & - \\ 55 & 3 \\ 20 & 6 \\ 30 & : \\ 25 & : \\ 30 & -\end{array}$

-
3
3
-

$\begin{array}{rrrrrr}- & - & - & - & - & - \\ 4 & 91 & 9 & - & - & - \\ 15 & 100 & - & - & - & - \\ 10 & 100 & - & - & - & - \\ - & - & - & - & - & -\end{array}$

$\begin{array}{rrr}- & - & - \\ 6 & 91 & - \\ 30 & 100 & - \\ - & - & - \\ - & - & -\end{array}$

2
3
3

$\begin{array}{rrrrrr}- & - & - & - & - & - \\ 15 & 91 & 9 & - & - & - \\ 10 & 100 & - & - & - & - \\ - & 100 & - & - & - & - \\ - & - & - & - & - & -\end{array}$

6
30

96
100

100

2

$\begin{array}{rrrrrr}- & - & - & - & - & - \\ 15 & 93 & 7 & - & - & - \\ 10 & 100 & - & - & - & - \\ - & 100 & - & - & - & - \\ - & - & - & - & - & -\end{array}$


Table 26. Herat

Barley - Sumn pest and Locust damage

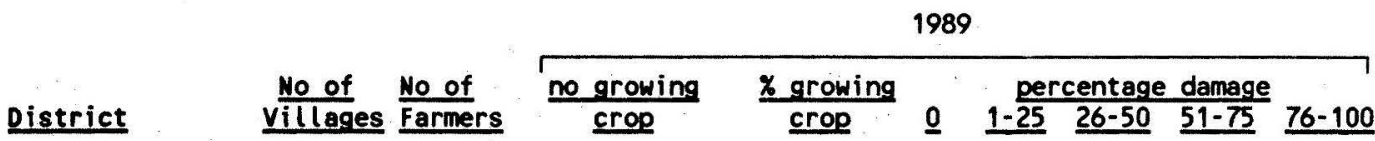

\begin{tabular}{cc}
1990. \\
\hline$\frac{\text { no growing }}{\underline{\text { crop growing }}} \frac{\text { crop }}{\underline{0}} \underline{1-25} \underline{\text { percentage damage }} \underline{\underline{26-50} \quad \underline{51-75}} \underline{76-100}$
\end{tabular}

Sunnpest

Percentage of Farmers assessing Own Damage

Enjeel

Gozarah

Pashtoon Zarg

Obey

Zendajan

Adreskan

$\begin{array}{ll}40 & 15 \\ 55 & 32 \\ 20 & 13 \\ 30 & 23 \\ 25 & 21 \\ 30 & 26\end{array}$

15
32
13
23
21
26

$\begin{array}{rrr}38 & 100 & - \\ 58 & 91 & 2 \\ 65 & 100 & - \\ 77 & 100 & - \\ 84 & 100 & - \\ 87 & 100 & -\end{array}$

Percentage of Farmers assessing Village Damage

Enjeel

Gozarah

Pashtoon Zars

Obey

Zendajan

Adreskan

$\begin{array}{ll}40 & 15 \\ 55 & 32 \\ 20 & 13 \\ 30 & 23 \\ 25 & 21 \\ 30 & 26\end{array}$

15
32
13
23
21
26

$\begin{array}{rrr}38 & 100 & - \\ 58 & 91 & - \\ 65 & 100 & - \\ 77 & 100 & - \\ 84 & 100 & - \\ 87 & 100 & \end{array}$

Locusts

Percentage of Farmers assessing Own Damage

Enjeel :

Gozarah

Pashtoon Zarg

Obey

Zendajan

Adreskan

Percentage of Farmers assessing Village Damage

Enjeel

Gozarah

Pashtoon Zarg

Obey

Zendajan

Adreskan

$\begin{array}{ll}40 & 15 \\ 55 & 32 \\ 20 & 13 \\ 30 & 23 \\ 25 & 21 \\ 30 & 26\end{array}$

8
11
4
6
5
6

15
32
13
23
21

6

15
32
13
23
21
26

$\begin{array}{rrr}38 & 100 & - \\ 58 & 98 & 2 \\ 65 & 100 & - \\ 77 & 100 & - \\ 84 & 100 & - \\ 87 & 100 & -\end{array}$

$\begin{array}{rr}38 & 100 \\ 58 & 91 \\ 65 & 100 \\ 77 & 100 \\ 84 & 100 \\ 87 & 100\end{array}$

12
32
14
24
20
25

$\begin{array}{rrrrrr}30 & 100 & - & - & - & - \\ 58 & 91 & 7 & 2 & - & - \\ 70 & 100 & - & - & - & - \\ 80 & 100 & - & - & - & - \\ 80 & 100 & - & - & - & - \\ 83 & 100 & - & - & - & -\end{array}$

$\begin{array}{ll}12 & 30 \\ 32 & 58 \\ 14 & 70 \\ 24 & 80 \\ 20 & 80 \\ 25 & 83\end{array}$

$\begin{array}{rrrrrr}30 & 100 & - & - & - & - \\ 58 & 91 & 2 & 7 & - & - \\ 70 & 100 & - & - & - & - \\ 80 & 100 & - & - & - & - \\ 80 & 100 & - & - & - & - \\ 83 & 100 & - & - & - & -\end{array}$

$\begin{array}{rrrrrr}30 & 100 & - & - & - & - \\ 58 & 91 & 7 & 2 & - & - \\ 70 & 100 & - & - & - & - \\ 80 & 100 & - & - & - & - \\ 80 & 100 & - & - & - & - \\ 83 & 100 & - & - & - & -\end{array}$

$\begin{array}{rrrrrrr}12 & 30 & 100 & - & - & - & - \\ 32 & 58 & 91 & 7 & 2 & - & - \\ 14 & 70 & 100 & - & - & - & - \\ 24 & 80 & 100 & - & - & - & - \\ 20 & 80 & 100 & - & - & - & - \\ 25 & 83 & 100 & - & - & - & -\end{array}$


Constraints on crop production 1989 Table 27

Problems as perceived by farmers

Baghlapi

\begin{tabular}{|c|c|c|c|c|c|c|c|c|c|c|c|c|c|c|c|c|}
\hline District & $\begin{array}{l}\text { Irrig } \\
\text { water }\end{array}$ & $\begin{array}{l}\text { Rain- } \\
\text { fall }\end{array}$ & $\begin{array}{l}\text { Farm } \\
\text { power }\end{array}$ & $\begin{array}{l}\text { Fert- } \\
\text { iliser }\end{array}$ & $\begin{array}{l}\text { War } \\
\text { effect }\end{array}$ & $\begin{array}{l}\text { Improv } \\
\text { seed }\end{array}$ & $\begin{array}{l}\text { Crop } \\
\text { protec }\end{array}$ & Labour & $\begin{array}{l}\text { Flood } \\
\text { damage }\end{array}$ & Insect & $\begin{array}{l}\text { Crop } \\
\text { disea }\end{array}$ & $\begin{array}{l}\text { Animal } \\
\text { disea }\end{array}$ & Birds & Rats & $\begin{array}{l}\text { Exten- } \\
\text { sion }\end{array}$ & Others \\
\hline $\begin{array}{l}\text { Laghlan } \\
\text { Puli Khumri } \\
\text { Mahrein }\end{array}$ & $\begin{array}{r}13 \\
15 \\
21\end{array}$ & $\begin{array}{l}5 \\
2 \\
27\end{array}$ & $\begin{array}{l}3 \\
0 \\
16\end{array}$ & $\begin{array}{l}6 \\
0 \\
2\end{array}$ & $\begin{array}{l}31 \\
19 \\
4\end{array}$ & $\begin{array}{l}15 \\
19 \\
14\end{array}$ & $\begin{array}{l}3 \\
0 \\
0\end{array}$ & $\begin{array}{l}5 \\
5 \\
1\end{array}$ & $\begin{array}{l}0 \\
0 \\
0\end{array}$ & $\begin{array}{l}1 \\
0 \\
1\end{array}$ & $\begin{array}{l}1 \\
0 \\
0\end{array}$ & $\begin{array}{l}0 \\
2 \\
0\end{array}$ & $\begin{array}{l}4 \\
12 \\
6\end{array}$ & $\begin{array}{l}1 \\
2 \\
4\end{array}$ & $\begin{array}{l}2 \\
9 \\
3\end{array}$ & $\begin{array}{l}11 \\
14 \\
1\end{array}$ \\
\hline
\end{tabular}

Takhar

\begin{tabular}{|c|c|c|c|c|c|c|c|c|c|c|c|c|c|c|c|c|}
\hline District & $\begin{array}{l}\text { Irrig } \\
\text { water }\end{array}$ & $\begin{array}{l}\text { Rain- } \\
\text { fall }\end{array}$ & $\begin{array}{l}\text { Farm } \\
\text { power }\end{array}$ & $\begin{array}{l}\text { Fert- } \\
\text { iliser }\end{array}$ & $\begin{array}{l}\text { War } \\
\text { effect }\end{array}$ & $\begin{array}{l}\text { Improv } \\
\text { seed }\end{array}$ & $\begin{array}{l}\text { Crop } \\
\text { protec }\end{array}$ & Labour & $\begin{array}{l}\text { Flood } \\
\text { damage }\end{array}$ & Insect & $\begin{array}{l}\text { Crop } \\
\text { disea }\end{array}$ & $\begin{array}{l}\text { Animal } \\
\text { disea }\end{array}$ & Birds & Rats & $\begin{array}{l}\text { Exten- } \\
\text { sion }\end{array}$ & Others \\
\hline $\begin{array}{l}\text { Taloqan } \\
\text { Farkhar } \\
\text { Eshkamesh } \\
\text { Khwa jaghar } \\
\text { Rustaq }\end{array}$ & $\begin{array}{l}0 \\
0 \\
1 \\
0 \\
0\end{array}$ & $\begin{array}{l}14 \\
100 \\
8 \\
44 \\
45\end{array}$ & $\begin{array}{l}0 \\
0 \\
4 \\
0 \\
19\end{array}$ & $\begin{array}{l}0 \\
0 \\
0 \\
5 \\
0\end{array}$ & $\begin{array}{l}10 \\
0 \\
2 \\
0 \\
0\end{array}$ & $\begin{array}{l}29 \\
0 \\
34 \\
4 \\
0\end{array}$ & $\begin{array}{l}1 \\
0 \\
4 \\
0 \\
0\end{array}$ & $\begin{array}{l}12 \\
0 \\
10 \\
0 \\
0\end{array}$ & $\begin{array}{l}0 \\
0 \\
0 \\
0 \\
0\end{array}$ & $\begin{array}{l}0 \\
0 \\
0 \\
0 \\
0\end{array}$ & $\begin{array}{l}4 \\
0 \\
4 \\
5 \\
0\end{array}$ & $\begin{array}{l}3 \\
0 \\
6 \\
0 \\
4\end{array}$ & $\begin{array}{l}2 \\
0 \\
1 \\
0 \\
0\end{array}$ & $\begin{array}{l}0 \\
0 \\
1 \\
0 \\
0\end{array}$ & $\begin{array}{l}1 \\
0 \\
1 \\
5 \\
0\end{array}$ & $\begin{array}{l}23 \\
0 \\
26 \\
36 \\
32\end{array}$ \\
\hline
\end{tabular}

Kunduz

\begin{tabular}{|c|c|c|c|c|c|c|c|c|c|c|c|c|c|c|c|c|}
\hline District & $\begin{array}{l}\text { Irrig } \\
\text { water }\end{array}$ & $\begin{array}{l}\text { Rain- } \\
\text { fall }\end{array}$ & $\begin{array}{l}\text { Farm } \\
\text { power }\end{array}$ & $\begin{array}{l}\text { Fert- } \\
\text { iliser }\end{array}$ & $\begin{array}{l}\text { War } \\
\text { effect }\end{array}$ & $\begin{array}{l}\text { Improv } \\
\text { seed }\end{array}$ & $\begin{array}{l}\text { Crop } \\
\text { protec }\end{array}$ & Labour & $\begin{array}{l}\text { Flood } \\
\text { damage }\end{array}$ & Insect & $\begin{array}{l}\text { Crop } \\
\text { disea }\end{array}$ & $\begin{array}{l}\text { Animal } \\
\text { disea }\end{array}$ & Birds & Rats & $\begin{array}{l}\text { Exten- } \\
\text { sion }\end{array}$ & Others \\
\hline $\begin{array}{l}\text { Kunctuz } \\
\text { Char Dara } \\
\text { Archi } \\
\text { Mazarat Imam } \\
\text { L jamabad } \\
\text { Oalae Zal }\end{array}$ & $\begin{array}{l}17 \\
22 \\
7 \\
30 \\
0 \\
29\end{array}$ & $\begin{array}{l}5 \\
2 \\
15 \\
0 \\
8 \\
14\end{array}$ & $\begin{array}{l}7 \\
7 \\
16 \\
15 \\
10 \\
13\end{array}$ & $\begin{array}{l}5 \\
4 \\
4 \\
2 \\
9 \\
5\end{array}$ & $\begin{array}{l}23 \\
14 \\
0 \\
0 \\
0 \\
7\end{array}$ & $\begin{array}{l}7 \\
11 \\
20 \\
20 \\
32 \\
4\end{array}$ & $\begin{array}{l}3 \\
3 \\
0 \\
0 \\
3 \\
4\end{array}$ & $\begin{array}{l}21 \\
23 \\
29 \\
18 \\
20 \\
16\end{array}$ & $\begin{array}{l}0 \\
0 \\
0 \\
3 \\
2 \\
0\end{array}$ & $\begin{array}{l}0 \\
0 \\
0 \\
0 \\
0 \\
0\end{array}$ & $\begin{array}{l}2 \\
5 \\
4 \\
7 \\
2 \\
1\end{array}$ & $\begin{array}{l}0 \\
1 \\
1 \\
0 \\
1 \\
0\end{array}$ & $\begin{array}{l}0 \\
0 \\
0 \\
0 \\
0 \\
1\end{array}$ & $\begin{array}{l}4 \\
2 \\
0 \\
0 \\
0 \\
0\end{array}$ & $\begin{array}{l}6 \\
4 \\
5 \\
6 \\
10 \\
4\end{array}$ & $\begin{array}{l}1 \\
2 \\
0 \\
0 \\
3 \\
1\end{array}$ \\
\hline
\end{tabular}

Badakhshan

District Irrig Rain Farm Fert- Har, Improv Crop Labour flood Insect Crop Animal Birds Rats Exten- Others
water fall power iliser effect seed protec


Constraints on crop production 1989 Table 28 Problems as perceived by farmers

Faryab

\begin{tabular}{|c|c|c|c|c|c|c|c|c|c|c|c|c|c|c|c|c|}
\hline District & $\begin{array}{l}\text { Irrig } \\
\text { water }\end{array}$ & $\begin{array}{l}\text { Rain- } \\
\text { fall }\end{array}$ & $\begin{array}{l}\text { Farm } \\
\text { power }\end{array}$ & $\begin{array}{l}\text { Fert- } \\
\text { iliser }\end{array}$ & $\begin{array}{l}\text { War } \\
\text { effect }\end{array}$ & $\begin{array}{l}\text { Improv } \\
\text { seed }\end{array}$ & $\begin{array}{l}\text { Crop } \\
\text { protec }\end{array}$ & Labour & $\begin{array}{l}\text { Flood } \\
\text { damage }\end{array}$ & Insect & $\begin{array}{l}\text { Crop } \\
\text { disea }\end{array}$ & $\begin{array}{l}\text { Animal } \\
\text { disea }\end{array}$ & Birds & Rats & $\begin{array}{l}\text { Exten- } \\
\text { sion }\end{array}$ & others \\
\hline $\begin{array}{l}\text { Almar } \\
\text { Belcheragh } \\
\text { Maymana } \\
\text { Yohistan } \\
\text { Pashtoon Kot } \\
\text { Shirin Tagab }\end{array}$ & $\begin{array}{l}4 \\
1 \\
5 \\
0 \\
2 \\
0\end{array}$ & $\begin{array}{l}14 \\
21 \\
5 \\
28 \\
13 \\
36\end{array}$ & $\begin{array}{l}2 \\
3 \\
2 \\
8 \\
2 \\
2 .\end{array}$ & $\begin{array}{l}3 \\
7 \\
10 \\
1 \\
7 \\
4\end{array}$ & $\begin{array}{l}9 \\
2 \\
12 \\
1 \\
8 \\
22\end{array}$ & $\begin{array}{l}6 \\
4 \\
6 \\
4 \\
2 \\
7\end{array}$ & $\begin{array}{l}14 \\
11 \\
18 \\
13 \\
12 \\
10\end{array}$ & $\begin{array}{l}0 \\
1 \\
1 \\
0 \\
0 \\
0\end{array}$ & $\begin{array}{l}0 \\
0 \\
0 \\
0 \\
0 \\
3\end{array}$ & $\begin{array}{l}36 \\
38 \\
27 \\
37 \\
33 \\
7\end{array}$ & $\begin{array}{l}7 \\
5 \\
6 \\
2 \\
7 \\
2\end{array}$ & $\begin{array}{l}2 \\
1 \\
0 \\
2 \\
3 \\
2\end{array}$ & $\begin{array}{l}0 \\
0 \\
0 \\
1 \\
1 \\
0\end{array}$ & $\begin{array}{l}0 \\
4 \\
3 \\
3 \\
6 \\
1\end{array}$ & $\begin{array}{l}3 \\
1 \\
4 \\
0 \\
2 \\
3\end{array}$ & $\begin{array}{l}1 \\
1 \\
0 \\
1 \\
1 \\
0\end{array}$ \\
\hline
\end{tabular}

Balkh

\begin{tabular}{|c|c|c|c|c|c|c|c|c|c|c|c|c|c|c|c|c|}
\hline District & $\begin{array}{l}\text { Irrig } \\
\text { water }\end{array}$ & $\begin{array}{l}\text { Rain- } \\
\text { fall }\end{array}$ & $\begin{array}{l}\text { Farm } \\
\text { power }\end{array}$ & $\begin{array}{l}\text { Fert- } \\
\text { iliser }\end{array}$ & $\begin{array}{l}\text { War } \\
\text { effect }\end{array}$ & $\begin{array}{l}\text { Improv } \\
\text { seed }\end{array}$ & $\begin{array}{l}\text { Crop } \\
\text { protec }\end{array}$ & Labour & $\begin{array}{l}\text { Flood } \\
\text { damage }\end{array}$ & Insect & $\begin{array}{l}\text { Crop } \\
\text { disea }\end{array}$ & $\begin{array}{l}\text { Animal } \\
\text { disea }\end{array}$ & Birds & Rats & $\begin{array}{l}\text { Exten- } \\
\text { sion }\end{array}$ & Others \\
\hline $\begin{array}{l}\text { Char Bolak } \\
\text { Chemtal } \\
\text { Dowlatabad } \\
\text { Nahre Shahi } \\
\text { Sholgera }\end{array}$ & $\begin{array}{l}42 \\
22 \\
41 \\
16 \\
3\end{array}$ & $\begin{array}{l}1 \\
10 \\
0 \\
22 \\
39\end{array}$ & $\begin{array}{l}2 \\
6 \\
3 \\
8 \\
7\end{array}$ & $\begin{array}{l}7 \\
0 \\
3 \\
0 \\
0\end{array}$ & $\begin{array}{l}14 \\
11 \\
12 \\
16 \\
2\end{array}$ & $\begin{array}{l}16 \\
7 \\
19 \\
7 \\
5\end{array}$ & $\begin{array}{l}3 \\
0 \\
0 \\
0 \\
1\end{array}$ & $\begin{array}{l}8 \\
7 \\
8 \\
8 \\
1\end{array}$ & $\begin{array}{l}0 \\
0 \\
0 \\
0 \\
0\end{array}$ & $\begin{array}{l}4 \\
21 \\
4 \\
8 \\
9\end{array}$ & $\begin{array}{l}2 \\
7 \\
9 \\
10 \\
20\end{array}$ & $\begin{array}{l}0 \\
3 \\
1 \\
3 \\
5\end{array}$ & $\begin{array}{l}0 \\
0 \\
0 \\
0 \\
0\end{array}$ & $\begin{array}{l}0 \\
4 \\
0 \\
3 \\
7\end{array}$ & $\begin{array}{l}0 \\
0 \\
0 \\
0 \\
0\end{array}$ & $\begin{array}{l}0 \\
0 \\
0 \\
0 \\
0\end{array}$ \\
\hline
\end{tabular}

Samangan

\begin{tabular}{|c|c|c|c|c|c|c|c|c|c|c|c|c|c|c|c|c|}
\hline District & $\begin{array}{l}\text { Irrig } \\
\text { water }\end{array}$ & $\begin{array}{l}\text { Rain- } \\
\text { fall }\end{array}$ & $\begin{array}{l}\text { Farm } \\
\text { power }\end{array}$ & $\begin{array}{l}\text { Fert- } \\
\text { iliser }\end{array}$ & $\begin{array}{l}\text { War } \\
\text { effect }\end{array}$ & $\begin{array}{l}\text { Improv } \\
\text { seed }\end{array}$ & $\begin{array}{l}\text { Crop } \\
\text { protec }\end{array}$ & Labour & $\begin{array}{l}\text { Fl ood } \\
\text { damage }\end{array}$ & Insect & $\begin{array}{l}\text { Crop } \\
\text { disea }\end{array}$ & $\begin{array}{l}\text { Animal } \\
\text { disea }\end{array}$ & Birds & Rats & $\begin{array}{l}\text { Exten- } \\
\text { sion }\end{array}$ & Others \\
\hline $\begin{array}{l}\text { Samangan, } \\
\text { Darae Souf } \\
\text { Khulm } \\
\text { Roye Doab }\end{array}$ & $\begin{array}{l}5 \\
0 \\
18 \\
2\end{array}$ & $\begin{array}{l}35 \\
42 \\
40 \\
39\end{array}$ & $\begin{array}{l}4 \\
3 \\
1 \\
3\end{array}$ & $\begin{array}{l}2 \\
0 \\
1 \\
1\end{array}$ & $\begin{array}{l}15 \\
5 \\
20 \\
6\end{array}$ & $\begin{array}{l}4 \\
4 \\
2 \\
1\end{array}$ & $\begin{array}{l}4 \\
2 \\
1 \\
12\end{array}$ & $\begin{array}{l}3 \\
0 \\
0 \\
1\end{array}$ & $\begin{array}{l}0 \\
0 \\
0 \\
0\end{array}$ & $\begin{array}{l}6 \\
14 \\
6 \\
13\end{array}$ & $\begin{array}{l}6 \\
7 \\
8 \\
7\end{array}$ & $\begin{array}{l}1 \\
3 \\
1 \\
0\end{array}$ & $\begin{array}{l}0 \\
0 \\
0 \\
0\end{array}$ & $\begin{array}{l}9 \\
10 \\
2 \\
13\end{array}$ & $\begin{array}{l}0 \\
0 \\
0 \\
0\end{array}$ & $\begin{array}{l}5 \\
10 \\
0 \\
2\end{array}$ \\
\hline
\end{tabular}

Jowz jan

\begin{tabular}{|c|c|c|c|c|c|c|c|c|c|c|c|c|c|c|c|c|}
\hline District & $\begin{array}{l}\text { Irrig } \\
\text { water }\end{array}$ & $\begin{array}{l}\text { Rain- } \\
\text { fall }\end{array}$ & $\begin{array}{l}\text { Farm } \\
\text { power }\end{array}$ & $\begin{array}{l}\text { Fert- } \\
\text { iliser. }\end{array}$ & $\begin{array}{l}\text { War } \\
\text { effect }\end{array}$ & $\begin{array}{l}\text { Improv } \\
\text { seed }\end{array}$ & $\begin{array}{l}\text { Crop } \\
\text { protec }\end{array}$ & Labour & $\begin{array}{l}\text { Flood } \\
\text { damage }\end{array}$ & Insect & $\begin{array}{l}\text { Crop } \\
\text { disea }\end{array}$ & $\begin{array}{l}\text { Animal } \\
\text { disea }\end{array}$ & Birds & Rats & $\begin{array}{l}\text { Exten- } \\
\text { sion }\end{array}$ & Others \\
\hline $\begin{array}{l}\text { Aqcha } \\
\text { Mengajek } \\
\text { Qarqin } \\
\text { Sang Charak }\end{array}$ & $\begin{array}{l}41 \\
41 \\
41 \\
2\end{array}$ & $\begin{array}{l}0 \\
0 \\
0 \\
37\end{array}$ & $\begin{array}{l}7 \\
15 \\
12 \\
5\end{array}$ & $\begin{array}{l}9 \\
7 \\
12 \\
0\end{array}$ & $\begin{array}{l}13 \\
12 \\
7 \\
1\end{array}$ & $\begin{array}{l}9 \\
6 \\
11 \\
10\end{array}$ & $\begin{array}{l}1 \\
0 \\
2 \\
3\end{array}$ & $\begin{array}{l}8 \\
10 \\
1 \\
3\end{array}$ & $\begin{array}{l}0 \\
0 \\
0 \\
1\end{array}$ & $\begin{array}{l}5 \\
3 \\
6 \\
22\end{array}$ & $\begin{array}{l}4 \\
5 \\
5 \\
10\end{array}$ & $\begin{array}{l}0 \\
0 \\
2 \\
0\end{array}$ & $\begin{array}{l}0 \\
0 \\
0 \\
0\end{array}$ & $\begin{array}{l}1 \\
0 \\
0 \\
6\end{array}$ & $\begin{array}{l}0 \\
0 \\
0 \\
0\end{array}$ & $\begin{array}{l}1 \\
0 \\
0 \\
1\end{array}$ \\
\hline
\end{tabular}


Constraints on crop production 1909 Table 29 Prablems as perceived by farmers

Badghis

\begin{tabular}{|c|c|c|c|c|c|c|c|c|c|c|c|c|c|c|c|c|}
\hline District & $\begin{array}{l}\text { Irrig } \\
\text { water }\end{array}$ & $\begin{array}{l}\text { Rain- } \\
\text { fall }\end{array}$ & $\begin{array}{l}\text { Farm } \\
\text { power }\end{array}$ & $\begin{array}{l}\text { Fert- } \\
\text { illiser }\end{array}$ & $\begin{array}{l}\text { War } \\
\text { effect }\end{array}$ & $\begin{array}{l}\text { Improv } \\
\text { seed }\end{array}$ & $\begin{array}{l}\text { Crop } \\
\text { protec }\end{array}$ & Labour & $\begin{array}{l}\text { Flood } \\
\text { damage }\end{array}$ & Insect & $\begin{array}{l}\text { Crop } \\
\text { disea }\end{array}$ & $\begin{array}{l}\text { Animal } \\
\text { disea }\end{array}$ & Birds & Rats & $\begin{array}{l}\text { Exten- } \\
\text { sion }\end{array}$ & Others \\
\hline $\begin{array}{l}\text { Chormach } \\
\text { Jawand } \\
\text { Morghab } \\
\text { cades }\end{array}$ & $\begin{array}{l}2 \\
3 \\
7 \\
11\end{array}$ & $\begin{array}{l}0 \\
0 \\
0 \\
0\end{array}$ & $\begin{array}{l}4 \\
1 \\
8 \\
3\end{array}$ & $\begin{array}{l}3 \\
2 \\
7 \\
5\end{array}$ & $\begin{array}{l}2 \\
2 \\
3 \\
4\end{array}$ & $\begin{array}{l}9 \\
7 \\
15 \\
11\end{array}$ & $\begin{array}{l}10 \\
8 \\
7 \\
10\end{array}$ & $\begin{array}{l}2 \\
1 \\
2 \\
1\end{array}$ & $\begin{array}{l}2 \\
0 \\
2 \\
0\end{array}$ & $\begin{array}{l}29 \\
38 \\
28 \\
21\end{array}$ & $\begin{array}{l}17 \\
14 \\
10 \\
17\end{array}$ & $\begin{array}{l}10 \\
12 \\
4 \\
10\end{array}$ & $\begin{array}{l}2 \\
4 \\
3 \\
4\end{array}$ & $\begin{array}{l}0 \\
3 \\
3 \\
2\end{array}$ & $\begin{array}{l}6 \\
6 \\
3 \\
3\end{array}$ & $\begin{array}{l}\mathbf{0} \\
\mathbf{0} \\
\mathbf{0} \\
\mathbf{0}\end{array}$ \\
\hline
\end{tabular}

